\title{
DESIGNER DUTY: EXTENDING LIABILITY TO \\ MANUFACTURERS FOR VIOLATIONS OF LABOR \\ STANDARDS IN GARMENT INDUSTRY SWEATSHOPS
}

\author{
LEO L. LAM $†$
}

The Fair Labor Standards Act ("FLSA") 1 regulates minimum wage, ${ }^{2}$ maximum hours, ${ }^{3}$ and child labor, ${ }^{4}$ making employers liable to their employees for violations of the Act. A substantial number of employers, however, particularly in labor-intensive industries, persistently violate these regulations or standards.

One such labor-intensive industry is today's garment industry, which is home to small sewing factories that consistently operate under substandard working conditions in immigrant neighborhoods throughout the country. ${ }^{5}$ These factories are commonly known as "garment sweatshops." The United States General Accounting Office defines "sweatshop" as "a business that regularly violates both wage or child labor and safety or health laws." According to federal and state officials, sweatshops exist throughout the United States. 7

At the bottom of the garment industry structure resides the provider of sweatshop labor-the garment worker. ${ }^{8}$ The garment

† B.S. 1988, UCLA; J.D. Candidate 1993, University of Pennsylvania. I would like to thank Professor Regina Austin and Professor Clyde Summers for their helpful suggestions and insightful criticisms. I also thank Dennis Hayashi and Gen Fujioka of the Asian Law Caucus for recommending and shaping this topic. Above all, I am grateful to Libby Liu, whose contributions to this Comment were as invaluable as the efforts of the editors of the Law Review.

129 U.S.C. $\$ \S 201-19$ (1988).

2 See id. \$ 206.

3 See id. \$ 207.

See id. § 212.

5 See infra notes 30-31 \& 64-69 and accompanying text.

${ }^{6}$ U.S. GEN. ACCT. OFF., "SWEATSHOPS" IN NEW YORK CITY: A LOCAL EXAMPLE OF A NATIONWIDE PROBLEM 1 (GAO/HRD-89-101BR, June 1989) [hereinafter GAO, NEW YORK CITY]; U.S. GEN. ACCT. OFF., "SWEATSHOPS" IN THE U.S.: OPINIONS ON THEIR EXTENT AND POSSIBLE ENFORGEMENT OPTIONS 1 (GAO/HRD-88-130BR, Aug. 1988) [hereinafter GAO, SwEATSHOPS]. The dictionary definition of "sweatshop" is "a shop or factory in which workers are employed for long hours at low wages and under unhealthy conditions." WEBSTER'S NINTH NEW COLLEGIATE DICTIONARY 1191 (1991).

7 See GAO, SWEATSHOPS, supra note 6, at 1-2, 19 (stating, however, that "[n]o empirical data exists to support or refute [this proposition] ${ }^{n}$ ). Apparel sweatshop conditions have received the most media attention in New York, Los Angeles, and San Francisco.

${ }^{8}$ See Steven A. Chin, Sweatshops: Bay's Ugly Secret, S.F. EXamIner, Feb. 13, 1989, 
worker is usually a Hispanic or Asian female immigrant ${ }^{9}$ who moved to an American metropolis ${ }^{10}$ with her family in search of economic opportunity. In contrast, at the top end of the industrial structure sits the foremost beneficiary of garment sweatshop laborthe apparel manufacturer. Unbeknownst to its avid consumers, this manufacturer is often one of the country's best-known apparel companies, including designer-name labels such as Guess? ${ }^{11}$ and Jordache. ${ }^{12}$

This Comment focuses on the current problems faced by the worker in the garment sweatshop, ${ }^{13}$ and argues for the extension of liability to the apparel manufacturer who engages in contracting out labor for violations of labor standards that occur in the garment sweatshop. Part I of this Comment provides a recent example, which is typical of the plight of the garment sweatshop worker. Part II describes the garment industry, ${ }^{14}$ providing an analysis of the relationship among the apparel manufacturer, the sweatshop owner, and the garment worker. In addition, Part II examines the business

at $\mathrm{Al} 10$ (diagramming the structure of the garment industry).

${ }^{9}$ See infra notes 51-55 and accompanying text.

${ }^{10}$ See infra notes 30-31 \& 64-69 and accompanying text.

11 Guess? has recently made an effort to do its part in attempting to clean up garment sweatshops. See infra note 176.

12 See Brian Murphy, Clothing Industry Sweatshops Making a Comeback, CHI. TRIB., June 2,1991 , at $8 \mathrm{C}$.

13 See generally GAO, SWEATSHOPS, supra note 6, at 32-84 (identifying major factors believed to be responsible for sweatshops).

${ }^{14}$ For a cursory overview of the apparel sweatshop industry, see Danielson v. Joint Bd. of Coat, Suit and Allied Garment Workers' Union, 494 F.2d 1230, 1234 (2d Cir. 1974) (describing the structure of the garment industry and its fierce competition for patronage of jobbers and inside manufacturers); Employing Lithographers v. NLRB, 301 F.2d 20, 26 (5th Cir. 1962) (describing improvements in working conditions for garment workers resulting from agreements between jobbers and unions); Botany Indus., Inc. v. New York Joint Bd., 375 F. Supp. 485, 494 (S.D.N.Y.), vacated on other grounds sub nom. Robb v. New York Joint Bd., 506 F.2d 1246 (2d Cir. 1974) (describing the jobber-contractor relationship); GAO, NEW YORK CITY, supra note 6, at 53-55 (describing the relationship between manufacturers, jobbers, and contractors); GAO, SWEATSHOP, supra note 6, at 35 (discussing the rapid growth of subcontracting); GuillermoJ. Greiner et al., On Machines and Bureaucracy: Controlling Ethnic Interaction in Miami's Apparel and Construction Industries, in STRUCTURING DIVERSITY: ETHNOGRAPHIC PERSPECTIVES ON THE NEW IMMIGRATION 65, 76-82 (Louise Lamphere ed., 1992) (describing the structure of work and social groupings common to sweatshops); Diane Yen-Mei Wong \& Dennis Hayashi, Behind Unmarked Doors: Developments in the Garment Industry, in MAKING WAVEs 159, 160-61 (Asian Women United of California ed., 1989) (discussing the origins and structure of the sweatshop industry). 
structure of the industry and the reasons why a typical garment worker continues to labor in a sweatshop.

Part III presents the obstacles blocking effective legal recourse by the garment worker. This Part will address, in particular, why current attempts at enforcement of labor standards fail, and the types of defenses used by the manufacturer to avoid liability for the worker's injuries.

Part IV studies the scope of the FLSA and the tests that determine whether a sufficient nexus exists between the manufacturer and the shop owner in order to extend to the manufacturer a legal duty of care towards the garment worker. Part V discusses the effectiveness of some current enforcement techniques and legislative proposals aimed at correcting sweatshop abuses by imposing liability on the apparel manufacturer for labor violations committed in its subcontractor's sweatshop. Part $\mathrm{V}$ also advances theories under FLSA which, in the absence of effective legislation, can be used to judicially extend liability to the manufacturer.

Part VI analyzes the exceptions made for the apparel industry in the National Labor Relations Act ("NLRA") ${ }^{15}$ under the garment industry proviso. ${ }^{16}$ Part VI propounds that extending liability to the manufacturer squares well with the special treatment afforded to the garment industry under the NLRA.

This Comment concludes that while Congress struggles with the enactment of legislation that would explicitly make the apparel manufacturer liable for labor violations occurring in garment sweatshops run by contractors, courts can and should interpret current labor laws to impose liability on that manufacturer. More specifically, the current state of the law coupled with the unique nature of the apparel industry enables judicial extension of liability to the manufacturer; and such an extension will ameliorate the current circumstances of the garment industry.

\section{A RECENT EXAMPLE}

On July 13, 1991, Raymond Kong and his wife, Nor Yee, closed the doors of eight sewing shops they owned ${ }^{17}$ in San Francisco and

1529 U.S.C. $\$ \S 151-69$ (1988).

${ }^{16}$ Id. $\$ 158(\mathrm{e})$.

${ }^{17}$ This problem has been a long-standing one throughout the United States. See, e.g., Susan Sward \& Bill Wallace, Problems at S.F. Garment Shops, S.F. CHRON., July 25, 1991 , at A1, A15 ("In a shrinking industry squeezed by recessionary pressures and intense competition from foreign manufacturers, financial collapse is not new. ... 
one in Oakland without any notice. At that time they owed more than $\$ 300,000$ in back wages to the over 450 seamstresses who were put out of work. ${ }^{18}$ The Kongs, who were reportedly bankrupt, ${ }^{19}$ disappeared. Rumors quickly surfaced that they had fled the country, conveniently leaving behind all financial and moral obligations to their sewing shop workers. ${ }^{20}$

The abandoned employees were mostly Southeast Asian immigrants, who had little or no understanding of English and even less understanding of their labor rights as employees. This scenario, unfortunately, illustrates the plight of a great number of garment workers. $^{21}$

In a fortunate turn of events for the Kongs' workers, the International Ladies Garment Workers Union ("ILGWU") provided help in filing claims for lost wages and in preventing large creditors from seizing the Kongs' assets before the lost wages were paid. ${ }^{22}$ Furthermore, Byer California, a clothing manufacturer which held production contracts with the Kongs, paid $\$ 200,000$ to the State Labor Commissioner's Office to help cover the unpaid wages of the workers in an act of apparent goodwill. ${ }^{23}$

Although the Kong case illustrates the experience of garment sweatshop workers, it differs from the typical case in certain salient aspects. First, most sweatshop owners do not possess assets that come close to covering their liabilities to their employees. ${ }^{24}$ In

[E]pisodes like [this] are indicative of a larger industry problem.").

${ }^{18}$ See Bay Area Sewing-Shop Owner Sought, S.F. CFroN., July 22, 1991, at A13; Bill Wallace, Judge Orders Back Pay for Garment Workers: Hundreds Lost Jobs When Couple's Shops Folded, S.F. CHRoN., Aug. 21, 1991, at A13.

${ }^{19}$ See Wallace, supra note 18, at A13.

${ }^{20}$ Dennis Hayashi, who represented the workers, provided this information. At the time, Hayashi was a labor attorney with the Asian Law Caucus, a civil rights, nonprofit legal service organization in San Francisco. Communication with Dennis Hayashi (Summer 1991) [hereinafter Communication with Hayashi].

21 Garment sweatshop owners often fall into financial problems causing them to lock up their shops and disappear. See Sward \& Wallace, supra note 17, at A1, A15. The low cost of opening up a sewing shop facilitates the practice of relocating shops by shop owners. See infra notes $38-40,107$ and accompanying text. This mobility poses a constant threat to the job security of the garment workers.

${ }^{22}$ See Bill Wallace, State Joins U.S. in Probe of Garment Firm: Labor Agencies Share Data on Failed Bay Area Company, S.F. CHRON., Aug. 8, 1991, at A16.

${ }^{23}$ See Kim-Vang Dang, Byer Califormia Donates \$200,000 to Pay Workers at Closed Contractor; Women's Apparel Wholesaler, WOMEN's WEAR DAILY, July 26, 1991, at 9; Bill Wallace \& Susan Sward, Tax Liens Filed Against Failed S.F. Garment Firm: IRS Seeks $\$ 75,000$ Withheld from Wages, S.F. CHRON., July 26, 1991, at A18.

24 See infra notes 38-43, 111-14 and accompanying text. 
addition, the Kong case attracted widespread media attention, which helped the workers secure assistance from the union and provided the incentive for the large manufacturer Byer California to donate money to help the workers recover lost wages. A majority of the cases do not generate any media attention, and thus public sentiment, either because they are too small or because they simply are not reported by the workers. ${ }^{25}$ Finally, it is extremely uncommon for a manufacturing company (such as Byer California) to take affirmative steps on supposedly moral grounds to help redress the injuries suffered by garment workers, especially when the case lacks the magnitude of media attention applied in the Kong case. ${ }^{26}$

Garment workers need sufficient legal means through which they can obtain relief from the injuries they sustain. Adequate relief cannot be accomplished by solely targeting the direct employer-the garment shop owner or contractor-for liability because the shop owner often has either insufficient or non-existent assets. ${ }^{27}$ The true beneficiary of the sweatshop system in the apparel industry, the manufacturer, should also be accountable for the problems that plague the industry. ${ }^{28}$

\section{NATURE OF THE GARMENT INDUSTRY}

The United States' garment industry is a very profitable one. Revenues in California alone gross billions of dollars annually. ${ }^{29}$

25 See infra notes 82-85, 89-102 and accompanying text.

${ }^{26}$ See, e.g., Dang, supra note 23, at 9 ("'Buyer [Byer California] approached us and voluntarily contributed the money. A gesture like that happens infrequently." (quoting Henry Huerta, Senior Deputy Labor Commissioner of California)).

${ }^{27}$ Vicious competition among sweatshop contractors puts many contractors in marginal financial conditions. See infra notes $41-43,216-18$ and accompanying text.

${ }^{28}$ Part II, infra notes $34-46$ and accompanying text, discusses the position occupied by the manufacturer or the retailer in the garment industry. Part IV, infra notes 130-64 and accompanying text, looks at current labor law to find a nexus by which courts can hold manufacturers liable for labor violations committed by their contractors. Essentially, the contention is that, in most cases, the manufacturer not only directly benefits from such violations, but also indirectly controls the conditions under which garment sweatshops operate; these operations constitute an integral part of the regular business of the manufacturer. The legal conclusion propounded in this comment is that typical case-by-case facts can adequately form the basis for denying apparel manufacturers who contract with sweatshop operators the use of the employee-contractor distinction. Under these circumstances, the manufacturer can be viewed as an "employer" of the sweatshop owner and thus can become liable for violations of the labor rights of the garment workers.

29 The San Francisco area itself has a five-billion-dollar-a-year industry, employing over 10,000 workers, most of whom are Chinese women. See Sward \& Wallace, supra note 17, at A1; see also Bob Baker, Union Targets Sweatshop Operators, L.A. TIMES, Apr. 
The three largest apparel centers in the United States are New York City, Los Angeles, and San Francisco, ${ }^{30}$ but this far-reaching industry also extends to many major cities in the South and Southwest such as Miami, New Orleans, and San Antonio. ${ }^{31}$ Nationwide, garment workers number over one million and the industry is dominated by small companies. ${ }^{32}$

The characteristics of the domestic apparel industry manifest many inherent economic advantages for manufacturers. For example, manufacturers have exceedingly favorable bargaining power relative to shop owners. It is ironic, therefore, that workers operate under "sweatshop" conditions in a substantial portion of the garment factories centered around our big cities. Furthermore, although a grave disparity in economic benefits exists between manufacturers and sweatshop workers, the apparel sweatshop situation has not received significant attention in legal literature..$^{33}$ Appreciation for a proposal to impose manufacturer liability requires an adequate understanding of the industry-an overview of its unique organization and characteristics.

27, 1990, at B3 (noting that there are approximately 90,000 garment workers in the garment district of downtown Los Angeles); Harry Bernstein, Labor: Sweatshops a Complex Problem, L.A. TIMES, July 10, 1990, at D3 (estimating industry revenues at six billion dollars a year in San Francisco).

${ }^{30}$ See Sward \& Wallace, supra note 17, at A1.

${ }^{31}$ See GAO, SWEATSHOPS supra note 6, at 26; infra notes 68-70 and accompanying text.

32 See Sward \& Wallace, supra note 17, at A15.

${ }^{33}$ So far, two law review works have addressed garment sweatshop conditions and offered possible improvements. These two works document the sweatshop conditions in garment factories centered in or around San Francisco's Chinatown in the 1970s and 1980s. See Harold P. Dygert III \& David Shibata, Chinatown Sweatshops: Wage Law Violations in the Garment Industry, 8 U.C. DAVIS L. REV. 63, 64-68 (1975) (examining the problem of wage law violations in San Francisco's Chinatown garment shops); Barbara E. Koh, Note, Alterations Needed: A Study of the Disjunction Between the Legal Scheme and Chinatown Garment Workers, 36 STAN. L. REV. 825, 827-35 (1984) (describing the plight of immigrants who work in Chinatown garment sweatshops). On the other hand, the overall garment sweatshop conditions themselves have been proliferously described in books, news articles, and legislative materials. 


\section{A. Business Structure and Roles}

The basic chain of business ${ }^{34}$ in the apparel industry consists of: the retailer, usually a department store or boutique; the manufacturer, ${ }^{35}$ for example, Levi-Strauss; the contractor (or a "subcontractor" relative to the manufacturer) or shop owner; and the garment worker. The largest profit margins are achieved at the top of the chain: the profit per garment to the retailer (typically greater than a 100 percent markup to the consumer) usually exceeds twice the profit to the manufacturer, which in turn exceeds twice that to the contractor. ${ }^{36}$

The manufacturer occupies the top position in the business chain: it designs the particular piece to be produced and dispatches the job to contractors. The manufacturer also provides the fabrics to be used. Some manufacturers may have their own cutting facilities, and a few may even have their own sewing and assembly factories. Calculation of the estimated retail price to consumers incorporates the labor costs, material costs, and the desired profit margin. The contractors run and own garment shops where they employ cutters, seamstresses, trimmers, and pressers to produce the garment.

Because of the traditional contracting system, the manufacturer, under typical circumstances, is relieved of any "direct" responsibilities to the garment workers, since they are technically employed by the contractor or shop owner. ${ }^{37}$ Thus, any liability for violations of labor standards in garment shops is generally assumed by the contractor, who is considered the culpable party. A closer look at

34 The chain of production in the apparel industry has remained virtually the same since the 1920s and 1930s. For a description of the industry as it existed in that era, see JACK HARDY, THE ClOTHING WORKERS: A STUDY OF THE CONDITIONS AND STRUGGLeS IN THE NEEDLE TRADES 149-65 (1935).

${ }^{35}$ The generic term "manufacturer" includes "jobbers." Jobbers design and merchandise apparel, and contract out sewing and pressing to the contractors. Jobbers are manufacturers who do not perform their own production. In the past, "jobbers" simply referred to producers of women's wear, whereas "manufacturers" referred to men's clothing. See id. at 153. This Comment will treat manufacturers and jobbers as the same since they perform basically the same functions.

${ }_{36}$ See, e.g., Chin, supra note 8 , at A10 (breaking down the profit for a $\$ 120$ skirt as follows: profit to the retailer is $\$ 60$; profit to the manufacturer is $\$ 25$; profit to the contractor is $\$ 10$ at a cost to the contractor of $\$ 25$, of which only $\$ 2.40$ goes to the worker).

${ }^{37}$ See infra notes 138-64, 180-90 \& 198-200 and accompanying text (discussing definition of the terms "employer" and "employee," and analyzing employeecontractor distinction); infra notes 191-97 \& 201-04 and accompanying text (applying analysis to garment industry). 
the apparel production contracting system, however, provides insight into the contractor's dilemma.

Many garment contractors began as sweatshop workers themselves who saved enough money to start their own shops. ${ }^{38}$ Starting a sewing shop requires relatively little capital. Typically, all that is needed is the money to purchase or lease a few sewing machines, rent space, and obtain a business permit. ${ }^{39}$ Sometimes an entire family will work in a factory to save enough money to go into the sewing business for themselves. ${ }^{40}$ Lack of education and business management experience, however, usually puts the contractor in a position of very limited bargaining power relative to the manufacturer.

Another reason for the disparate distribution of bargaining power is that the ease of entry into the contracting business results in a large number of shop owners competing among themselves, forcing them to lower their contracting bids to win business from manufacturers. ${ }^{41}$ The overabundance of contracting shops and the resulting underbidding competition between contractors compels them to cut either the workers' wages, or their profits, or both. ${ }^{42}$ The knowledge that there are always other shops eager to take any manufacturer's order for a minimal profit poses a constant threat to the individual contractor.

Meanwhile, manufacturers benefit from this competition and often deliberately pit contractors against each other to achieve the lowest possible price. ${ }^{43}$ The sweatshop system prevails because manufacturers find substantial savings in using low-priced labor

${ }^{38}$ See Dygert III \& Shibata, supra note 33, at 64; Koh, supra note 38, at 828; Liz Mullen, Korean Business People Find Prosperity in Contract Garment Work, L.A. Bus. J., Feb. 4, 1991, at 32, 36.

${ }^{39}$ See Dygert III \& Shibata, supra note 33, at 64; See Wong \& Hayashi, supra note 14 , at 160 .

${ }^{40}$ See Constance L. Hays, Immigrants Strain Chinatown's Resources, N.Y. Times, May 30, 1990, at B1, B4 (interviewing Professor Betty Lee Sung, Chairwoman of the Asian Studies department at City College in New York).

${ }^{41}$ See HARDY, supra note 34, at 156; Wong \& Hayashi, supra note 14, at 160; Koh, supra note 33, at 827-28; Mullen, supra note 38 , at 36.

42 See HARDY, supra note 34, at 156; Dygert III \& Shibata, supra note 33, at 64; Wong \& Hayashi, supra note 14, at 160; William Serrin, Combating Garment Sweatshops Is an Almost Futile Task: The New Sweatshop, N.Y. TIMES, Oct. 13, 1983, at B1.

43 See Jack Chen, The ChInese of AMERICA 238 (1980); Dygert III \& Shibata, supra note 33, at $64 ; \mathrm{Koh}$, supra note 33 , at 828 . As previously indicated, this type of situation accurately depicts the apparel industry structure even as it existed 60 years ago. See HARDY, supra note 34 , at 156, 161-63. 
contracts rather than maintaining their own sewing and assembly labor force. Through subcontracting, the manufacturer can save on expenses such as overhead and rent. In addition, as discussed above, the manufacturer has access to a virtually unlimited supply of contract labor without any responsibility to the labor force. Avoiding responsibility for the conditions under which the garment worker labors is perhaps the foremost reason for the development of the contracting system. ${ }^{44}$ Moreover, this system allows the manufacturer to avoid any concerns with production details and to focus on generating designs based on market developments. ${ }^{45}$ The use of contracted labor allows the manufacturer to calculate production costs with complete disregard for the costs and circumstances of labor, and the great fluctuations in volume that result from the apparel industry's seasonal variations. ${ }^{46}$

\section{B. Exploitation of Immigrant Labor}

Recently, apparel manufacturing firms have shifted their operations from foreign countries to the United States in efforts to avoid stiff import quotas and shipping costs. ${ }^{47}$ Some manufacturers who had originally moved factories abroad (to locations such as Asia and Central America) from the United States in the 1960s and 1970s in search of cheap labor are now moving operations back home. ${ }^{48}$ Uncertain political outlooks (particularly in Hong Kong $^{49}$ and parts of Latin America), increased labor costs abroad, and instances of poor workmanship have further spurred domestic production. ${ }^{50}$

14 See CHEN, supra note 43, at 237; Dygert III \& Shibata, supra note 33, at 65; see also HARDY, supra note 34, at 155-56 (discussing the savings deliberately incurred by manufacturers in utilizing the system of sub-manufacturing).

45 See Dygert III \& Shibata, supra note 33, at 65.

${ }^{16}$ See, e.g., HARDY, supra note 34 , at 205-07 (describing general problems associated with "seasonal" employment of clothing workers).

17 See Chin, supra note 8, at A1.

${ }^{48}$ See Stephanie Strom, U.S. Garment Makers Come Home, N.Y. TIMES, Oct. 8, 1991, at D1.

19 Hong Kong reverts from British rule back to China in 1997.

50 See Strom, supra note 48; see also Elizabeth Hudson, Silencing Sewing Machines, La Mujer Obrera Strikes, WASH. POST, May 30, 1991, at A3 (statement of Cecilia Rodriguez, founder of La Mujer Obrera, a women's activist group in El Paso, Texas, noting that even as larger manufacturers move to third-world countries where labor is cheaper, workers in the United States are exploited by smaller sweatshops that open and close quickly and frequently). 
Fortunately for the industry, the rapidly expanding flow of immigrants, both legal and illegal, ${ }^{51}$ into major cities in the United States coincides with the growing demand for domestic apparel production. This influx of immigrants provides a large pool of easily exploited workers to meet the production demand. ${ }^{52}$ Currently, Hispanics and Asians account for nearly the entire labor force in the apparel industry. ${ }^{53}$ Women are also overrepresented in the apparel industry. ${ }^{54}$ These new immigrants are driven to sweatshop employment by their financial needs as well as their lack of English language skills, creating a situation ripe for exploitation. ${ }^{55}$

51 See GAO, SWEATSHOPS, supra note 6, at 34-85; see, e.g., Hays, supra note 40, at B4 (citing statistics that show an increase in the number of legal-from 24,787 in 1985 to 28,717 in 1988-and apprehended illegal-from 196 in 1987 to 984 in 1989immigrants from China alone, with far more suspected than are caught). Illegal immigrants generally fall into two categories: those who overstay their visas and those who are smuggled into the country. See id. Smuggling networks operate over the east, west, and south coasts of the United States, often charging anywhere between $\$ 30,000$ and $\$ 50,000$ dollars per person without any guarantees. See id; Al Kamen, A Dark Road from China to Chinatown, WASH. Post, June 17, 1991, at A1.

52 See Chin, supra note 8, at A1, A10; see also Linda S. Bosniak, Exclusion and Membership: The Dual Identity of the Undocumented Worker Under United States Law, 1988 WIS. L. REV. 955, 982, 1021-24 (discussing cases that have held that undocumented workers are covered by the terms of the federal labor protection statutes); Kenneth B. Noble, Investigators Find Sweatshops Are in Resurgence, N.Y. TIMES, Sept. 4, $1988, \S 1$, part 1, at 26 (addressing parallel problems of sweatshops in both apparel and restaurant industries).

53 At the turn of the century, Jewish and Italian immigrants made up nearly the entire labor force in the industry. See HARDY, supra note 34, at 18; WILliaM M. LEISERSON, ADJUSTING IMMIGRANT AND INDUSTRY 206-07 (1969). These demographics have since changed. See GAO, SWEATSHOPS, supra note 6, at 2, 23-24 (estimating 60\% Hispanic and 35\% Asian); Noble, supra note 52, sec. 1, part 1, at 26 (also estimating $60 \%$ Hispanic and 35\% Asian); see also BeTtY LEE SuNG, A SURVEY OF CHINESEAMERICAN MANPOWER AND EMPLOYMENT 82-83 (1976) (commenting that Chinese immigrants have supplanted Jewish and Italian laborers in the garment industry).

${ }^{54}$ See Alex Stepick, Miami's Two Informal Sectors, in THE INFORMAL ECONOMY: STUdies IN ADVANCED AND Less DEVELOPED CounTrIes 111, 117 (Alejandro Portes et al. eds., 1989); Wong \& Hayashi, supra note 14, at 159.

55 See GREgORY DEFREITAS, INEQUALITY AT WORK: HISPANICS IN THE U.S. LABOR FORCE 113 (1991) (arguing that Hispanic workers in the apparel industry are more vulnerable to employer violations of labor standards than white workers); R.G. Gregory et al., Why Are Lowskilled Immigrants in the United States Poorly Paid Relative to Their Australian Counterparts?, in IMMIGRATION, TRADE, AND THE LABOR MARKET 385, 389-405 (John M. Abowd \& Richard B. Freeman eds., 1991) (analyzing earnings gaps between immigrants and native-borns in the United States and Australia in the textile, clothing, and footwear industries). 


\section{Sweatshop Conditions}

The most common violations occurring in garment sweatshops are sub-minimum wages and lack of overtime pay. ${ }^{56}$ Shop owners often pay their workers less than half the federal minimum wage. ${ }^{57}$ Moreover, shop owners frequently violate child labor laws by employing under-aged children for work weeks that surpass the maximum number of hours allowed per week under the FLSA. ${ }^{58}$

Beyond financial wage-related hardships lie the physical hardships that the garment worker must endure. ${ }^{59}$ The typical garment sweatshop environment is damp and hot, ${ }^{60}$ cramped with

${ }^{36}$ See GAO, SwEATSHops, supra note 6, at 8. According to Dennis Hayashi, "garment sweatshops go unchecked, with rampant violations of wage and hours laws." Communication with Hayashi, supra note 20.

${ }^{57}$ See, e.g., Testimony of ILGWU President Jay Mazur at Labor Department Hearing on Homework in the Women's Apparel Industry, Daily Lab. Rep., Apr. 4, 1989, at D1 (statement of Mazur: $\$ 65-70$ for 50 hours per week of work) [hereinafter Testimony, Daily Lab. Rep.]; Chin, supra note 8, at A10 (1989: \$2.00 an hour for 12 hour work days); AM. FEDERATIONIST, Aug. 2, 1986, at 10 (commenting that "wages [were] commonly as low as $\$ 1$ to $\$ 1.50$ an hour") (testimony of Mazur).

58 See U.S. GEN. ACCT. OFF., CHILD LABOR VIOLATIONS AND SWEATSHOPS IN THE U.S. 3 (GAO/T-HRD-90-18, Mar. 1990) [hereinafter GAO, CHILD LABOR]; GAO, NEW YORK CITY, supra note 6, at 8-9 (describing the situation of a Mexican immigrant boy who worked in a shop which was so cold that "workers could run their fingers under the cutter and not even know it ${ }^{n}$ ); GAO, SWEATSHOPS, supra note 6, at 21; Michael Specter, Illegal Child Labor Surging in U.S.: Immigrant Schoolgirls Toil in Modern-Day Sweatshops, WASH. PosT, Apr. 14, 1991, at A1. A sweep of 200 San Francisco sweatshops found more than 70 shops in violation of child labor laws. Experts suspect that the problem is worse in New York City's Chinatown alone. See id. at A8.

${ }^{59}$ One journalist recently rated a garment worker's occupation as one of the ten worst jobs in the nation. See Tom Juravich, The 10 Worst Jobs in America Are Making Millions Miserable, STAR TRIB., Sept. 3, 1991, at 11A (noting that garment workers work for sub-minimum wages and at substandard conditions).

${ }^{60}$ The dampness and heat result from the lack of space, which forces shop owners to place the boilers for the pressers in the same room as the sewing machines. See William Serrin, After Years of Decline, Sweatshops Are Back, N.Y. TIMES, Oct. 12, 1988, at A1. Serrin also gives the following description:

Often garment industry workers must walk three or four flights to their factories, up dark, dingy, littered hallways. Elevators, when they exist, are often old and small and overburdened; it would take too long to wait for them.

Cloth seems to fly through the machines as the seamstresses make blouses, skirts, dresses, trousers.

The factories hum with the noise of machines-electric cutting knives, sewing machines, pressing machines. Radios play loudly, and there is the babble of foreign languages and the steam and smell of the food that workers often eat at their benches. Floors often are littered with cloth remnants and stacked with cut goods or rolled goods. The factories are hot or cold, depending on the season. 
piles of highly flammable materials, poorly lit, with blocked exits, battered doors, and grime-coated windows; it is generally unsafe and unsanitary. ${ }^{61}$ Inside, one can find each seamstress sitting in a crowded space, wearing a surgical mask if lucky, otherwise improvising with pieces of cloth over her face to prevent excessive inhalation of lint and dust, "hunched over a sewing machine . . . pushing fabric past a speeding needle as quickly as her hands [can] manage." ${ }^{\prime 62}$ According to a report issued by the General Accounting Office, safety and health hazards include "overcrowded rooms with poor ventilation, stairways in disrepair, unsanitary bathrooms, children playing near dangerous cutting machines, and workers preparing food next to their machines and eating from plates on littered floors." 63

In New York City alone, there are an estimated 6000 garment shops, ${ }^{64}$ including "at least 2000 unlicensed shops in lofts, back rooms and garages." ${ }^{\prime 65}$ In over 5000 investigations since 1987, the State Labor Department has found in addition to 2100 unregistered shops, 500 minimum wage violations, 2000 reports of unsafe working conditions, and over 600 child-labor violations. ${ }^{66}$ In San Francisco, out of 1300 inspections of garment shops, state investiga-

Id. at $\mathrm{B} 4$.

61 See Michael Freitag, New York Is Fighting Spread of Sweatshops, N.Y. TIMES, Nov. 16,1987 , at A1. Many in the industry recall the 1911 fire which struck the Triangle Shirtwaist Company in New York and killed 146 workers. Labor and fire officials believe that conditions in today's sweatshops are just as hazardous. See Firefighters Salute Victims of Triangle Disaster as Union Members Rally, PR NEWSWIRE, Mar. 28, 1989.

${ }^{62}$ Chin, supra note 8 , at A1 (asserting that many workers' experiences are often worse than they would have endured in their countries of origination).

63 GAO, NEW YORK CITY, supra note 6 , at 8.

64 The General Accounting Office estimated in 1989 that 7000 apparel manufacturing firms operate in New York, including 4500 sweatshops and over 1200 which are not even registered. See GAO, NEW YORK CITY, supra note 6, at 22 (citing estimates from the state's Apparel Industry Task Force); Hal Taylor, U.S. Report Labels Over Half of NYC's Makers as Sweatshops, WOMEN's WEAR DAILY, June 28, 1989, at 15. The State Labor Department estimated that $70 \%$ of the contractors in New York City "do not meet the minimum requirements and have a blatant disregard for the laws." Freitag, supra note 61, at B4. "Pinpointing the actual number of shops is impossible. . . . Many seem to open and close overnight, either to avoid being investigated or to relocate to sites where rent is cheaper. And once located, the boarded-up windows and metal gates make them virtually inaccessible to non-employees." Chin, supra note 8 , at $\mathrm{A} 10$.

${ }^{65}$ Brian Murphy, supra note 12 , at $8 \mathrm{C}$.

${ }^{66}$ See id. 
tors found violations of labor standards in seventy-two percent of the shops, and issued 952 citations. $^{67}$

Apparel sweatshops, however, do not exist only in New York and California; they exist "wherever a large, illegal alien workforce [is] willing to work for sub-minimum wages. ${ }^{.68}$ Labor officials have inspected and reported sweatshops in a wide range of cities such as Chicago, Dallas, Miami, and Washington, D.C., each of which is home to a substantial immigrant population. ${ }^{69}$

To exacerbate the situation, the increasing number of small subcontractors ${ }^{70}$ makes it difficult to compile accurate statistics on conditions and violations. The low cost of opening shops and the instability of workloads due to seasonal variations contribute to a very mobile industry. ${ }^{71}$ Even if comprehensive statistics were gathered, however, they might not accurately represent workers' wages and hours because shop owners are able to circumvent wage and hour standards by the methods of compensation utilized.

\section{a. Piecework Wage System}

The piecework wage system, long-established in the industry, ${ }^{72}$ describes the process by which most garment workers are paid. A worker is paid for each garment she assembles or produces instead

67 See Sward \& Wallace, supra note 17, at A15 (concluding that there was a total of over \$1 million in fines). A 1990 ILGWU survey of 230 downtown shops in San Francisco found $60 \%$ paying below the minimum wage and $80 \%$ not paying overtime. See id.

${ }^{68}$ Rick Pullen, Harsh Penalties Urged for Sweatshop Operators, Apparel Manufacturing Sweatshops, WOMEN's WEAR DAILY, Oct. 14, 1988, at 15 (noting that the GAO found that 100 New Orleans apparel sweatshops employed 5000 workers); see also GAO, SWEATSHOP, supra note 6 , at 2.

69 The five mentioned cities were home to over one-fifth of the estimated 9.8 million legal and illegal aliens counted in the 1980 census. See GAO, SWEATSHOPS, supra note 6 , at 47 . Of the respondents to a GAO sweatshop survey in the 49 states (all except Oregon), only those from Alaska and Hawaii believed that sweatshops were not a problem in their respective states. See id. at 24-26. Those states that reported serious or multiple problems in the apparel industry included New York, California, New Jersey, Illinois, Indiana, Ohio, Michigan, Wisconsin, Minnesota, Pennsylvania, Florida, Louisiana, Texas, Oregon, and even Washington, D.C. See id.

${ }^{70}$ See id. at 35 (citing dramatic increase in number of contractors with less than 20 employees). The Census Bureau in 1982 estimated that over $40 \%$ of the domestic apparel shops employed fewer than 10 persons. See Pullen, supra note 68, at 15.

71 Analysts blame the difficulty of estimation on the "high turnover and frequent movement of the shops." Alexander Reid, Thriving Sweatshops Feed on Immigrants" Desire for Work, N.Y. TMES, Mar. 25, 1986, at B2.

72 See HARDY, supra note 34, at 191-93 (commenting on compensation by piece rates in the 1920 s and 1930 s); Koh, supra note 33 , at 828; Serrin, supra note 60 , at B4. 
of for the amount of time she works. Because of this system, wages can vary over a very wide range since the pay depends on how fast a seamstress works; the faster she sews, the more she will earn. ${ }^{73}$ Piecework wage employers characterize the system as efficient because it provides workers with an incentive to work quickly. Labor officials, however, argue that the piecework wage system affords contractors a pretext for avoiding compliance with the minimum wage law and is just one of the ways of circumventing labor standards. ${ }^{74}$

\section{b. Homework}

Shop owners also send seamstresses home with piecework to be completed for the next day in order to avoid paying legally mandated overtime wages. ${ }^{75}$ Violations of homework laws ${ }^{76}$ tend to coincide with violations of child labor laws because the tight financial circumstances of garment families often force children to participate in the work process, especially in domestic settings. ${ }^{77}$

Homeworkers usually buy all their own equipment and pay for work-related utilities and transportation costs. ${ }^{78}$ Homework contributes to the inaccurate recording of hours worked, ${ }^{79}$ thereby providing shop owners with another means of hiding noncompliance with wage and hour laws. While sweatshop owners and contractors continue to find creative ways to avoid compliance with

${ }^{73}$ Wages can run as low as $\$ 1.00$ an hour and as high as $\$ 9.00$ an hour at a rate of a few cents per item completed; a typical skirt would involve sewing two darts, a waistband, and a zipper, and cutting a slit. See Serrin, supra note 60, at B4. Pressers make even less. See CHEN, supra note 43, at 237.

${ }^{74}$ Critics say "it makes the workers both slave driver and slave." Serrin, Decline, supra note 60 , at $B 4$.

${ }^{75}$ See CHEN, supra note 43, at 237; HARDY, supra note 34, at 217-18 (arguing that, despite repeated attempts to regulate homework, it was a widely accepted business practice during the 1930s).

76 See 29 U.S.C. \$ 211(d) (1988).

77 See Testimony, Daily Lab. Rep., supra note 57, at D2 (testimony of ILGWU President Jay Mazur at a hearing on homework in the women's apparel industry). Supporters of homework argue that it provides the employee with greater work flexibility. See id.

${ }^{78}$ See id.

${ }^{79}$ Many garment workers do not keep homework records for two reasons. First, they fear it will cause their shop owners to have problems with labor officials. See id. at D3; see also text accompanying infra note 100. Second, many workers are "nonEnglish-speaking immigrants" who are "unsophisticated" and simply incapable of "keeping painstaking records." Testimony, Daily Lab. Rep., supra note 57, at D3; see also infra notes 89-94 and accompanying text (addressing lack of English skills). 
labor standards, garment workers are unable to use affirmative means to assert their labor rights.

\section{Lack of Unionization}

Unionization may be a key to protection of the garment worker, but studies show that the overwhelming majority of sewing shops are non-union shops. ${ }^{80}$ There is some evidence that unions help to improve working conditions. In recent years, wages have declined in all but unionized factories, which are primarily located in the Northeast. $^{81}$

Garment workers who are illegal aliens often choose not to participate in unions because they fear an increased possibility of deportation if they draw attention to themselves. ${ }^{82}$. Furthermore, $^{2}$ a continuing tradition of exclusionary and discriminatory practices in union memberships discourages many garment workers from seeking membership. ${ }^{83}$ Most non-union garment workers are

${ }^{80}$ In 1989 , for example, studies estimated that as many as 400 of the approximately 500 sewing shops in the San Francisco area were non-union shops. See Chin, supra note 8, at A10 (basing its estimate on information supplied by Asian Immigrant Women Advocates, a workers' education group based in Oakland, California). No more than a few thousand of the estimated 90,000 workers in the garment district in downtown Los Angeles are organized. See Baker, supra note 29, at B3. Overall, the membership of the ILGWU has "plummeted to 150,000 from 300,000 in the last 10 years." Id. at B4. Today, there are 5000 registered garment shops in California. See Bill Wallace, State Agency to Raid "Sweatshops": Tough Enforcement of Labor Laws Planned at Garment Factories, S.F. CHRON., Aug. 23, 1991, at B4. Workers in the thousands of small shops, including sweatshops, are so desperately in need of work that they would not risk their jobs in order to improve working conditions. Most of the sewing shops, therefore, are not unionized. See Serrin, Combating, supra note 42 , at B1, B4.

${ }^{81}$ See Bernstein, supra note 29 , at D3; see, e.g., Wong \& Hayashi, supra note 14 , at 120 (95\% of New York Chinatown garment workers belong to the ILGWU compared to $1 \%$ in San Francisco).

82 Some survey evidence suggests, however, that the likelihood of union membership increases, even for undocumented aliens, with the duration of residence in the United States. See DEFreITAS, supra note 55, at 234; see generally Catherine L. Merino, Compromising Immigration Reform: The Creation of a Vulnerable Subclass, 98 YALE L.J. 409, 415-16, 423 (1988) (noting that undocumented workers appeal to potential employers "precisely because they will not report working conditions and employment arrangements that violate federal and state statutes ${ }^{n}$ ); $\mathrm{M}$. Patricia Fernandez-Kelly \& Anna M. Garcia, Informalization at the Core: Hispanic Women, Homework, and the Advanced Capitalist State, in THE INFORMAL ECONOMY: STUDIES IN ADVANCED AND LESS DEVELOPED CoUNTRIES 253 (Alejandro Portes et al. eds., 1989) ("WW]hether because of lack of information, fear, or the need to maximize a meager income, most underground workers avoid compliance with the law, in collusion with the employers who frequently abuse them.").

${ }^{83}$ See SUNG, supra note 53, at 124; see, e.g., HERMAN FELDMAN, RACIAL FACTORS 
further deterred from unionization because they not only fear that the union will fail to support them, ${ }^{84}$ but they also suspect that unionization will not make working conditions any better. ${ }^{85}$

Evasion of the union is a primary reason for the very existence of the contracting system. ${ }^{86}$ The contracting system provides the manufacturer the option of sending work to small, mobile, nonunion shops that can easily evade union surveillance, instead of much larger in-house production plants that are easy to locate and thus subject to union supervision. ${ }^{87}$ The very nature of the industry, therefore, hinders movement towards union control. The manufacturer often utilizes the contracting system itself as an antiunion measure. ${ }^{88}$ Although unionization might cure violations, it would appear that the sheer size of the apparel industry would relegate attempts at mass unionization to long-term endeavors.

IN AMERICAN INDUSTRY 92, 108, 115, 221-22 (1931) (describing racial tensions reflected in unions in the early twentieth century); LEISERSON, supra note 53, at 210 . 14 (arguing that ethnic tension caused the Amalgamated Garment Workers to split off from the United Garment Workers in 1914); Wong \& Hayashi, supra note 14, at 170-71 (noting the resistance of some local unions to the needs of their Asian members).

${ }^{84}$ See, e.g., Dygert III \& Shibata, supra note 33 , at 78 (noting the "strained relationship" between the ILGWU and Chinatown garment workers, resulting largely from the union's ineffective policing of its contracts).

${ }^{85}$ See CHEN, supra note 43, at 237; Serrin, supra note 42, at B1, B4. For example, one author argues that the ILGWU might fear possible layoffs due to increased foreign competition if female workers obtain pay equity increases relative to male workers. See NORMA M. RICCUCCI, WOMEN, MINORITIES, AND UNIONS IN THE PUBLIC SECTOR 159-61 (1924) (noting that Sol Chaikin, president of the ILGWU, argues for general wage increases, rather pay equity increase, in an effort to avoid foreign competition).

${ }^{86}$ See Danielson v. Joint Bd. of Coat, Suit \& Allied Garment Workers' Union, 494 F.2d 1230, 1234 (2d Cir. 1974); HARDY, supra note 34, at 156.

${ }^{87}$ See HARDY, supra note 34, at 156; see also supra notes 38-40; infra note 107 and accompanying text (discussing factors and effects associated with the mobility of the garment shops). The mobility of the shops contributes to the prevalence of runaway shops in the industry. See Employing Lithographers v. NLRB, 301 F.2d 20, 26 (5th Cir. 1962) (observing that the contracting system is constantly changing and garment workers are difficult to organize); Wong \& Hayashi, supra note 14, at 165-66.

88 The factors mentioned here are by no means exhaustive. A complete discussion of the relationships involved between garment workers and unions goes beyond the scope of this Comment. Here the concern is with the effect of those relationshipsthat is, the lack of unionization. 


\section{Lack of Other Options}

The primary factor confining garment workers to their occupations is the lack of English skills. ${ }^{89}$ Many seamstresses, moreover, are untrained for any other type of work: ${ }^{90}$ "most believe that sewing is their sole means of survival in this country. ${ }^{n 1}$ Even academically and professionally trained immigrants resort to toiling in garment sweatshops. For example, many former engineers, ${ }^{92}$ teachers, ${ }^{93}$ and architects ${ }^{94}$-all professionals in their country of origin-are now sweatshop laborers in the United States. This system puts additional pressure on current garment workers who must face the reality that incoming immigrants, hungry for any job, can easily replace them.

Seamstresses often choose to work in garment shops because shops owners accommodate their family obligations and schedules. ${ }^{95}$ More fundamentally, the majority of garment workers are simply tolerant of "life's harsh struggles, ${ }^{, 96}$ and are accustomed to third-world working conditions.

${ }^{89}$ Illiteracy in English precludes people from many job opportunities. Thus, immigrants who speak no English whatsoever are limited to even fewer employment opportunities. See, e.g., Wong \& Hayashi, supra note 14, at 161-62 (providing examples of the effects of a lack of English skills in Asian immigrants); Hays, supra note 40 , at B1, B4 (noting that many garment workers, although overqualified for manual labor, have no other employment opportunities).

${ }^{90}$ See CHEN, supra note 43, at 237; Wong \& Hayashi, supra note 14, at 161-63.

91 Chin, supra note 8, at A10.

92 See Hays, supra note 40 , at B1, B4.

93 See id. at B1.

94 See Chin, supra note 8, at A1.

95 As true today as it has been for decades, many seamstresses do not believe that they are being exploited. They cite their own minimum job skills, and the absence of strict work controls such as time-punching, for their general job satisfaction. See CHEN, supra note 43 , at 237. They are able to drift in to work after seeing their husbands off to work and children off to school; take time out to shop for the family; pick up their children; bring their small children with them to the shop; and if they want to do extra work, they can even take it home at piecework rates (illegally). See id.

96 For example, as one journalist writes:

They have survived war, prison, famine, terrifying voyages across pirateinfested seas and long stints in refugee camps. Now, in the land of their dreams, thousands of Vietnamese immigrants spend long days hunched over sewing machines in sweatshops ....

Some earn as little as $\$ 1$ an hour. Most are glad to get it. Beside them toil Latino immigrants who have fled impoverished homelands . . . .

Sonni Efron, Sweatshops In Suburbia: Old Problem, New Twist, L.A. TIMES, Nov. 26, 1989, at A1. 


\section{Lack of Complaints from Garment Workers}

Just as new immigrants are generally unfamiliar with American culture, garment workers are usually unaware of their labor rights. In fact, they have an inherent distrust of the legal system derived from their experiences in their home countries. This contributes to the ineffectiveness of the ILGWU's attempts to organize garment workers, as discussed above. ${ }^{97}$

More importantly, garment workers typically believe that they are at the mercy of the shop owner. They feel lucky to have jobs and are desperate to keep them. ${ }^{98}$ This provides garment workers with multiple rationales against bringing forward a complaint.

First, complaining about pay or mandatory overtime can mean facing a retaliatory dismissal and being blacklisted at other local apparel shops. ${ }^{99}$ Second, garment workers believe that if officials discover any labor violations in their workplaces, this will force shop owners out of business, leaving the workers themselves without jobs. ${ }^{100}$ Third, as discussed above, undocumented workers fear that filing an official complaint may not only fail to improve shop conditions, but may also lead to investigations of their individual immigration statuses and possible deportation. ${ }^{101}$

Some employees even develop personal relationships with their supervisors or shop owners. For instance, employees may, despite

${ }^{97}$ See supra notes 80-88 and accompanying text. One journalist writes, "Many of these women are from countries where union equals communism equals bad." Michael Robertson, Empowering the Women of the Sweatshops, S.F. CHRON., Apr. 24, 1990 , at B3, B5.

${ }^{98}$ See, e.g., supra note 95 and accompanying text (discussing some of the benefits garment workers perceive in their occupations).

${ }^{99}$ See Chin, supra note 8, at A10:

It is not uncommon for workers to give supervisors and bosses gifts of

liquor and food just to stay in favor with them.

"If your supervisor tells you to sit there, you sit there; if he tells you to

kneel, you kneel," said one outraged seamstress who ... requested her name not be used for fear of losing her job.

See also Wong \& Hayashi, supra note 14, at 164-65 (giving reasons why garment workers ignore problems in sweatshops).

100 Communication with Hayashi, supra note 20.

101 Most undocumented workers have a fear of Anglo authorities in general. Without a green card, an illegal alien is likely to take any job and work under any conditions. See, e.g., Murphy, supra note 12, at 8C (interviewing an illegal alien from the Dominican Republic). Sometimes the worker is afraid that an investigation will lead to penalties for illegally supplementing personal income with welfare payments. See Clean Up the Sweatshops, L.A. TimES, Nov. 29, 1989, at B6. 
being exploited, perceive culturally based obligations or loyalties to the shop owner for providing work and financial security, albeit at subsistence level. ${ }^{102}$ Thus, without any form of outside remedy, the typical garment worker's experience will remain dismal.

\section{Obstacles Blocking Effective Legal Recourse}

\section{A. Lack of Adequate Enforcement}

Cutbacks in labor law enforcement at both state ${ }^{103}$ and federal levels have indirectly contributed to the exploitation of immigrants in apparel sweatshops. A lack of resources committed to the enforcement ${ }^{104}$ of state and federal worker-protection laws renders labor regulations inadequate. ${ }^{105}$ Budget cuts at both state and federal levels have forced the government to understaff agencies and departments that handle labor inspections in sweatshop industries. ${ }^{106}$

The lack of stringent enforcement, however, is not the sole problem, particularly when such enforcement is directed only at the

102 Some shops actually survive and provide employment for several successive generations of workers from one family. Communication with Dennis Hayashi, supre note 20; see, e.g., Specter, supra note 58, at A8 ("It is common for women . . . to bring their infants to work with them. When they are old enough, they learn to help ... or make some other contribution ....").

${ }^{103}$ For instance, Jose Millan, California's Senior Deputy Labor Commissioner, while estimating that two-thirds of the state's garment shops are in violation of state licensing and registration law, claims that his agency has been spread thin in the struggle to enforce labor standards covering other industries such as agriculture. See Sward \& Wallace, supra note 17, at A15; see also GAO, SWEATSHOPS, supra note 6, at 36-48 (offering an account of the limits on enforcement in general).

104 The two main federal enforcement agencies are the Wage and Hour Division ("WHD") and the Occupational Safety and Health Administration ("OSHA"), both of which are within the Department of Labor.

${ }^{105}$ In its report on sweatshops, the GAO noted that government regulations are ineffective because of the limited coordination among enforcement agencies, the insufficient staff resources under inspection priorities, and the inadequate penalties for violations under present law. See GAO, SwEATSHOPS, supra note 6, at 2-3, 36-48.

106 See GAO, NEW YORR CITY, supra note 6, at 3, 32-40 (reporting a lower than $10 \%$ inspection rate); GAO, SWEATSHOPS, supra note 6 , at $45-47$ (estimating that $16 \%$ of apparel shops were inspected by WHD and 14\% by OSHA between 1983 and 1987); Bernstein, supra note 29, at D3 (" [C]ompanies abusing workers must first be caught, and there aren't enough labor law enforcement officers to make the exploiters give more than a fleeting thought to that remote possibility."); Noble, supra note 52, sec. 1, part 1, at 26 (noting that sweatshop operations are not a top priority for agencies such as OSHA). Some simply feel that the government cares little about the exploitation of the garment worker. See Fernandez-Kelly \& Garcia, supra note 82, at 253-54. 
sweatshop owner. Even if garment workers were to seek legal protection from or remedies for violations of their labor rights, the law would not accommodate them sufficiently.

\section{B. Lack of Adequate Relief from Sweatshop Owners}

\section{Problems of Proof}

Labor investigators regularly face evidentiary problems created by sweatshop owners' false or missing wage records. Owners can always relocate, using new equipment and new workers. ${ }^{107}$ As a result, garment workers, afraid of driving shop owners elsewhere, refrain from filing complaints and feel compelled to overstate wages and understate hours in order to protect their bosses' businesses and thus their own jobs. ${ }^{108}$

Moreover, as discussed earlier, the piecework wage system and the practice of homework enable shop owners to circumvent standards for minimum wage and overtime pay. ${ }^{109}$ Dubious and

${ }^{107}$ As discussed in Part II, operating a sewing shop requires a minimal monetary investment. See supra notes $38-40$ and accompanying text. It is generally easy for the shop owner to relocate in search of cheaper-or more obedient-labor by simply transporting equipment (sewing machines and pressers can be readily moved) to the new location or re-renting equipment at that location. A constantly relocating sweatshop operation is commonly known as a "stitch-and-ditch" business. Communication with Hayashi, supra note 20. "Stitch-and-ditch" shops are analogous to runaway shops, which are temporarily closed and relocated by employers for anti-union purposes.

${ }^{108}$ A three-month investigation in Sacramento, California, in which a reporter went undercover as a sewing shop operator, revealed the following:

- Timecards usually do not reflect actual hours worked and it is normal for workers to labor 12 hours a day, six days a week when San Francisco manufacturers are ordering. In one shop, new employees sign time cards and never see them again.

- Some employees are paid by check but must split the money with others who are not listed in the shop's records. Others are paid in cash so they can illegally receive welfare payments, a practice that also violates federal withholding laws.

- In some cases workers pay their employers to fill out forms stating they earned more than they did, later translating into higher unemployment benefits from the state.

Regional News: Califormia, PROPRIETARY TO THE UNITEd PREsS INT'L, Feb. 10, 1985.

${ }^{109}$ See supra notes $72-79$ and accompanying text. The practice of homework also violates health and safety standards since many garment workers live in ghetto residences that are, not surprisingly, ill-suited for performing factory-volume cutting, sewing, and assembly functions. 
even outright fraudulent record-keeping can insulate the shop owner from investigative or judicial findings of labor law violations.

\section{Inadequacies of Available Remedies}

Regulations aimed at removing sweatshop conditions in the garment industry, like the FLSA, have generally focused on the shop owner and not the manufacturer. State regulations, ${ }^{110}$ such as registration and licensing requirements for sewing shops that employ more than a certain number of workers; sanctions against the distribution of industrial homework to employees; signposting requirements that facilitate the locating of shops by labor officials; and requirements for employee record-keeping, all entail penalties against the shop owners for any discovered violations. These regulations, however, are ineffective for several reasons.

First, even if back wages and damages are recoverable, such as in the Kongs' situation, ${ }^{111}$ such potential recovery is usually insufficient to prompt an employee to risk losing her job ${ }^{112}$ and being blacklisted ${ }^{113}$ for breaking ranks and creating dissension. Furthermore, many shop owners who violate wage and hour laws or owe back wages are insolvent. Thus, the garment worker is further deterred from initiating a lawsuit by the futility of seeking damages from an insolvent party. ${ }^{114}$

Furthermore, penalties such as those under the FLSA ${ }^{115}$ are generally inadequate to deter potential violators. ${ }^{116}$ Because of a lack of federal sanctions, shop owners are less likely to comply with labor regulations. ${ }^{117}$ Even when state penalties are imposed

110 See, e.g., CAL. [LAB.] CoDE $\$ \S 2670-82$ (West 1989 \& Supp. 1992) (California apparel industry regulations); N.Y. [LAB.] LAW $\$ \$ 340$ to $316-b$ (McKinney 1986 \& Supp. 1992) (New York apparel industry and industrial homework regulations).

${ }_{11}$ See supra notes 17-26 and accompanying text.

112 See supra notes 82, 89-101 and accompanying text.

113 Being blacklisted eliminates a worker's future employment opportunities, and can also result in ridicule or social ostracism. Communication with Hayashi, supra note 20.

114 One seamstress described an episode in which her employer pressured his employees to return their checks-which were in fact awarded by the labor commission for back wages-in order to keep their jobs. See Chin, supra note 8, at A10.

115 For example, the FLSA does not explicitly establish monetary penalties for record-keeping violations. See 29 U.S.C. $\$ \$ 201-19$ (1988).

116 See GAO, NEW YORK CITY, supra note 6, at 3, 40-41; GAO, SwEATSHOPS, supra note 6 , at $47-48$.

117 See Pullen, supra note 68, at 15 (statement of Representative Charles E. Schumer of New York). 
which increase with repeat violations, ${ }^{118}$ sweatshop owners generally consider paying fines (on the rare occasions when they are caught) as simply a cost of conducting business. ${ }^{119}$ The penalties, when assessed, are often inconsequential compared to the total profits earned from sweatshop labor. ${ }^{120}$ The profits generated by sweatshop labor simply exceed the cost of the penalties for labor standard violations given the low probability that those penalties might be imposed.

These inadequacies, among others, of limiting liability for labor violations to the shop owner demonstrate the need to expand the scope of liability to include the manufacturer, since the manufacturer benefits the most from the structure of the garment industry. Emphasis, then, should shift from penalizing shop owners for labor standard violations to deterring manufacturers from patronizing sweatshop labor. ${ }^{121}$ Manufacturers, however, have been able to absolve themselves of their complicity in perpetuating sweatshop conditions.

\section{Lack of Adequate Relief from Manufacturers}

The manufacturer enjoys not only the benefits of the fierce bidding competition between sweatshop contractors to win and keep production contracts, but also moral and legal insulation from liability to the garment workers for violations of their labor rights.

118 Representative Schumer of New York proposed a bill, which would have established criminal sanctions and allowed authorities to seize garments, but this bill failed to pass. See Murphy, supra note 12, at $8 \mathrm{C}$.

119 "[Fines are] a cost of doing business. ... They put it in the file with the electric bill and the telephone bill." Serrin, Combating, supra note 42 , at B4 (statement of Joseph Danahy, ILGWU's organizing director).

${ }^{120}$ See, e.g., Bernstein, supra note 29, at D3 (explaining that penalties are a negligible cost, totaling less than one-fiftieth of one percent of the industry's gross revenue); Sonni Efron, "Hot Goods" Law Revived as Anti-Sweatshop Tool, L.A. TIMES, Nov. 28, 1989, at A3 (noting that California enforcement efforts have made only a small dent in the sweatshop industry). The sweatshop owner who does secure a production contract can only afford to hire seamstresses to work under sweatshop conditions in order to sustain profit margins. Keeping the garment workers employed under sweatshop conditions is also the only way the shop owner can afford to underbid the competition for contracts with the manufacturer. Thus, the market provides incentives for the shop owner to circumvent labor standards at all stages of the bidding game, and it perpetuates the existence of sweatshop conditions in the apparel industry. See id. at A18-A19.

${ }^{121}$ See Efron, supra note 96, at A38 ("Some argue that labor police have never succeeded in crushing sweatshops in the past and are unlikely to do so now because the market demands them."). 
The major policy argument against manufacturer liability is that under a free-market theory, an ignorant buyer should not be held accountable for the seller's wrongdoings.

Many manufacturers claim or feign ignorance with respect to the deplorable conditions under which garment sweatshop employees work, and the labor violations that exist therein. ${ }^{122}$ Manufacturers defend themselves against liability by arguing that an imposition of liability would unfairly force them to subsidize the monitoring of their subcontractors for labor law compliance. ${ }^{123}$ Opposers of manufacturer liability assert that the burden of regulation of the garment industry should rest upon the government and not the manufacturers. ${ }^{124}$ They also deny the existence of any barriers that prevent victimized workers from suing manufacturers in court. ${ }^{125}$

In addition to these moral justifications, manufacturers can claim legal insulation from compliance with the worker protection provisions of the FLSA ${ }^{126}$ for the garment workers by invoking the employee-contractor distinction. ${ }^{127}$ An independent contractor is one who contracts to do something for the contractee but who is not controlled by the contractee or subject to the contractee's control with respect to the manner in which the performance of the

122 See Bernstein, supra note 29, at D3. Manufacturers often insist that they are not responsible for or aware of the "highly publicized abuse of workers on the contractors' payroll" while supposedly "[r]espectable companies ... don't like the sleazy portion of their industry, and ... deplore[] it." Id.

123 See infra note 174 and accompanying text; see also Ralph Frammolino, Legislation Targeting Sweatshops Vetoed, L.A. TIMES, Aug. 25, 1990, at A29 (reporting that the former Governor of California rejected manufacturer liability legislation on these grounds).

124 See id. Former Governor of California, George Deukmejian, upon vetoing a proposed manufacturer liability bill, claimed that the bill, if signed, would assign to manufacturers "the impossible duty of constantly overseeing their business associates for labor law violations or be liable for those violations." Teresa Simons, Deukmejian Vetoes Garment Sweatshop Bill, PROPRIETARY TO THE UNITED PRESS INT'L, Aug. 24, 1990 (quoting former Governor Deukmejian).

125 See Frammolino, supra note 129, at A29.

126 See 29 U.S.C. $\$ \S 201-19$ (1988).

127 If the sweatshop owner is effectively treated as an "employee" or agent of rather than an "independent contractor" to the manufacturer, then the manufacturer becomes liable for violations of the labor rights of garment workers by the sweatshop owner. For examples of the historical treatment of independent contractor status in employer-employee relationships, see American Fed'n of Musicians v. Carroll, 391 U.S. 99 (1968) (musicians); Local 24, Int'l Bhd. of Teamsters v. Oliver, 958 U.S. 283 (1959) (truckers); Columbia River Packers Ass'n v. Hinton, 315 U.S. 143 (1942) (fishermen). 
contract is undertaken. ${ }^{128}$ The FLSA sets labor standards and regulations in an employer-employee relationship. "Independent contractors," however, do not fall within the FLSA definition of "employee,"129 and the status of the garment sweatshop owner as an independent contractor can free the manufacturer from liability for labor law violations occurring in the sweatshop. In the absence of adequate forms of protection for the garment worker, the legal immunity of the manufacturer must be re-evaluated.

\section{SCOPE OF FLSA}

Judicial precedent makes it clear that U.S. labor laws extend protection to undocumented aliens as well as citizen or resident workers in the United States. ${ }^{130}$ On the other hand, no precedent has involved the extension of liability to any manufacturer for labor

128 See RESTATEMENT (SECOND) OF AGENCY § 2 (1958).

${ }^{129}$ See, e.g., Rutherford Food Corp. v. McComb, 331 U.S. 722, 728-31 (1947) (applying employee-contractor distinction). Congress clearly intended to exclude independent contractors from the definition of "employee" and used the agricultural processing industry as a parallel example:

[T] he minimum wage provisions of this Act [should] be extended to certain sharecroppers and tenant farmers. The test of coverage for these persons will be the same test that is applied to determine whether any other person is an employee or not. . . . Coverage is intended in the case of certain socalled sharecroppers or tenants whose work activities are closely guided by the landowner or his agent. These individuals, called sharecroppers and tenants, are employees by another name. . . True independent-contractor sharecroppers or tenant farmers will not be covered; they are not employees.

H.R. REP. No. 1366, 89th Cong., 2d Sess. 31 (1966) (emphasis added), reprinted in Jeanne M. Glader, A Harvest of Shame: The Imposition of Independent Contractor Status on Migrant Farmworkers and Its Ramifications for Migrant Children, 42 HASTINGS L.J. 1455,1456 n.10 (1991).

${ }^{130}$ The Supreme Court in Sure-Tan, Inc. v. NLRB, 467 U.S. 883 (1984), held that the term "employee" under the National Labor Relations Act (NLRA) includes undocumented aliens since the NLRA did not list undocumented or illegal aliens in its specifically enumerated exemptions. See id. at 891-92; see also NLRB v. Apollo Tire Co., 604 F.2d 1180, 1182 (9th Cir. 1979) (recognizing that the NLRB consistently interprets "employee" under the NLRA to include aliens). The Supreme Court moreover found that the Immigration and Nationality Act ("INA") does not make it unlawful to hire an illegal alien and reasoned that its decision would remove the benefits to the employer (such as substandard wages and working conditions) of hiring illegal aliens, thereby providing less incentive for aliens to enter the United States illegally. See Sure-Tan, 467 U.S. at 892-94. See generally Bosniak, supra note 52 , at 982, 1021-24 (commenting on the Sure-Tan Court's treatment of undocumented aliens); Merino, supra note 82, at 422-23 (adding that the protection of undocumented aliens adds to the protection of lawful workers). 
law violations in apparel sweatshops that perform contracted jobs. An analysis, however, of the language, legislative intent, and judicial interpretation of the FLSA demonstrates that despite the inadequate protection and remedies garment sweatshop workers have so far received, the law is clearly intended to protect them.

\section{A. Language and Intent}

The FLSA was enacted to remove the types of "deleterious working conditions"131 that exist in garment sweatshops. ${ }^{132}$ The FLSA definition of "employer" includes "any person acting directly or indirectly in the interest of an employer in relation to an employee." 133 Similarly, the FLSA broadly defines "employ" to include "to suffer or permit to work." ${ }^{\text {134 }}$ Such expansive language $^{135}$ indicates that Congress intended to achieve legislative remedial purposes despite "legal" barriers posed by artificial or deceptive contractual veils. ${ }^{136}$

The legislative history of the FLSA ${ }^{137}$ reveals that Congress intended to give the Act a broad reach. A primary purpose of the FLSA is to protect workers with little or no bargaining power: ${ }^{138}$ the lowest paid, hardest worked, and least organized.

151 Glader, supra note 129 , at 1468.

132 Cf. [1C] ARTHUR LARSON, THE LAW OF WORRMEN's COMPENSATION § 43.42, at 8-23 (1991) (" $[$ C]ompensation law is concerned . . . with injuries to [the employee] as a result not only of his own activities (controlled by the employer as to details) but of those of co-employees, independent contractors and other third persons (some controlled by the employer, and others not).").

13329 U.S.C. § 203(d) (1988).

134 Id. $\$ 203(\mathrm{~g})$.

135 "The term 'employee' is defined by most statutes to include every person in the service of another under any contract of hire, express or implied." LARSON, supra note $132, \S 43.00$, at $8-1$.

${ }^{136}$ See, e.g., U.S. v. Silk, 331 U.S. 704, 711-12 (1947) (denouncing “adroit schemes" by employers to avoid responsibilities imposed by legislation to benefit employees).

${ }^{137}$ The Senate report on proposed 1966 amendments to the FLSA discussed the legislative intent of Congress and provided that:

The Fair Labor Standards Act was enacted in 1938 to meet the economic and social problems of that era. Low wages, long working hours, and high unemployment plagued the Nation, which was then in the midst of an unprecedented depression. The policy of the act, as set forth therein, was to correct and as rapidly as practicable to eliminate labor conditions detrimental to the maintenance of the minimum standard of living necessary for health, efficiency, and general well-being of workers.

S. REP. No. 1487, 89th Cong., 2d Sess. 1-3 (1966).

138 "'These are the most exploitable people, the least educated, who don't know their rights." Pullen, supra note 68, at 15 (quoting the aide to Representative Charles 
Today's typical garment sweatshop worker fits that description. It is unlikely that the drafters of the protective legislation meant to preclude garment workers from relief for violations of their labor rights on the basis of the employee-contractor distinction (with respect to the sweatshop owner), ${ }^{139}$ which is meant to free a contractee from responsibility for the actions of a contractor whose manner of executing a contracted job is subject to little or no control by the contractee. Today's garment sweatshop worker will not receive the protection that the FLSA requires unless liability is extended to the manufacturer.

\section{B. Judicial Interpretation}

The scope of the legislative intent behind the FLSA is wide, and judicial interpretation of the expansive language in the FLSA has been correspondingly broad. ${ }^{140}$ Judicial interpretation has resulted in the development of two different tests for deciding cases involving the employee-contractor distinction: the right-to-controldetails test and the relative-nature-of-work test.

\section{Restatement (Second) of Agency and the Right to Control Details}

Endless varieties of cases involving a labor relationship have invoked judicial construction of the term "employee." Indeed, judicial interpretation of the term "employee" has "probably produced more reported cases than any definition of status in the modern history of law."141 Most courts, however, have agreed that the tests for determining employee-contractor status are similar to that given in the Restatement (Second) of Agency. ${ }^{142}$ Without a

E. Schumer of New York).

${ }^{139}$ This Comment will later propose legal theories under which liability can be judicially extended to the manufacturer. See infra notes 180-218 and accompanying text.

${ }^{140}$ See, e.g., McLaughlin v. Seafood, Inc., 867 F.2d 875, 877 (5th Cir. 1989) ("The remedial purposes of the FLSA require the courts to define 'employer' more broadly than the term would be interpreted in traditional common law applications.") (footnote omitted).

${ }^{141}$ LARSON, supra note $132, \S 43.10$, at 8-1.

${ }^{142}$ See id., at 8-3, 8-6. Larson draws an analogy between employee and servant (under the RESTATEMENT) for common law purposes. See id. at 8-2. The REstateMENT provides that:

[i]n determining whether one acting for another is a servant or an independent contractor, the following matters of fact, among others, are considered: 
concrete set of rules, the interpretation of the employee-contractor distinction has involved case-by-case factual determinations ${ }^{143}$ based upon ten factors listed in the Restatement. ${ }^{144}$ These include the extent of control over the details of work and the type of occupation involved. ${ }^{145}$

Common law application of the Restatement resulted in the emergence of the right to control the details of the work-or, alternatively, the extent of such control-as the single most important factor. ${ }^{146}$ An evaluation of the employee-contractor distinction based on this factor is known as the right-to-control-details test. $^{147}$ The underlying principle of the right-to-control-details test is that the more control the superior (or "master") has over the work of the subject (or "servant"), the more appropriate it is for the superior to assume responsibility for the subject's actions. ${ }^{148}$

(a) the extent of control which, by the agreement, the master may exercise over the details of the work;

(b) whether or not the one employed is engaged in a distinct occupation or business;

(c) the kind of occupation, with reference to whether, in the locality, the work is usually done under the direction of the employer or by a specialist without supervision;

(d) the skill required in the particular occupation;

(e) whether the employer or the workman supplies the instrumentalities, tools,

and the place of work for the person doing the work;

(f) the length of time for which the person is employed;

(g) the method of payment, whether by the time or by the job;

(h) whether or nor the work is a part of the regular business of the employer;

(i) whether or not the parties believe they are creating the relation of master

and servant; and

(j) whether the principal is or is not in business.

RESTATEMENT (SECOND) OF AGENCY § 220(2) (1958).

${ }^{143}$ See, e.g., Magenau v. Aetna Freight Lines, 360 U.S. 273, 278 (1959) (holding that the existence of an employer-employee relationship is for the jury to determine).

144 See LARSON, supra note $132, \$ 43.20$, at $8-6$.

145 See id. $\$ \S 43.20-43.30$, at 8-6 to $8-10$.

${ }^{146}$ See id. $\$ 43.30$, at 8-10; Patricia Davidson, The Definition of "Employee" Under Title VII: Distinguishing Between Employees and Independent Contractors, 53 U. CIN. L. REV. 203, 207 (1984) (noting that " $[\mathrm{i}] \mathrm{t}$ is this element of control that distinguishes the employer-employee relationship from the independent contractor relationship at common law").

${ }^{147}$ See infra notes 183-97 and accompanying text (applying the test to the structure of the garment industry).

148 Analogous to respondeat superior, the manufacturer would be liable for an injury to a person, or property, of another resulting from the actions of the shop owner, which was committed within the scope of the shop owner's "employment." The extension of liability to the manufacturer is also supported by an analysis of the economics involved in the doctrine of vicarious liability. For example, Alan Sykes contends that the efficiency of vicarious liability, at least in part, turns on the agent's 


\section{Economic Reality Doctrine and Relative Nature of Work}

In NLRB v. Hearst Publications, Inc., ${ }^{149}$ the Supreme Court advanced a broad interpretation of the terms in the NLRA. ${ }^{150}$ The Court held that the statute was not to be construed solely under common law standards and legal classifications but rather that it "must be understood with reference to the purpose of the Act and the facts involved in the economic relationship. 151

The approach, adopted in Hearst, of analyzing the purpose of social welfare legislation ${ }^{152}$ and the underlying economic facts of a case in determining employee-contractor status became known as the "economic reality" doctrine. ${ }^{153}$ A subsequent trilogy of cases, United States v. Silk, ${ }^{154}$ Rutherford Food Corp. v. McComb, ${ }^{155}$ and Bartels v. Birmingham, ${ }^{156}$ affirmed this approach in analyzing legislation that followed the NLRA, including the FLSA.

The Silk Court reasoned that:

a constricted interpretation [of the terms in the FLSA] ... would only make for a continuance, to a considerable degree, of the difficulties for which the remedy was devised and would invite adroit schemes by some employers to avoid the immediate burdens at the expense of the benefits sought by the legislation. ${ }^{157}$

ability to pay judgments under a rule of personal liability. See generally Alan O. Sykes, The Economics of Vicarious Liability, 93 YALE L.J. 1231, 1239-55 (1984) (suggesting that the rule of vicarious liability is almost always more efficient than personal liability in the event of agent insolvency, regardless of the principal's ability to observe the agent's "loss-avoidance" behavior).

149322 U.S. 111 (1944).

${ }^{150}$ See Hearst, 322 U.S. at 129 (stating that the term "employee" should be defined broadly, taking into account "the history, context, and purposes of the Act" as well as the specific relationship in question). The NLRA regulates relations between employers and employees, covering unfair labor practices. See National Labor Relations Act, 29 U.S.C. $\$ \S 151-69$ (1988).

${ }^{151}$ Hearst, 322 U.S. at 120, 129.

152 See, e.g., Davidson, supra note 146, at 209-10 ("[T]he statute must be interpreted in light of the evils to be corrected and the end to be achieved.").

${ }^{153}$ Larson distinguishes the economic reality concept from thinking of the "employee category as a fixed and immutable one, for all times and for all purposes." LARSON, supra note 132 , 44.41 , at 8-11.

154931 U.S. 704, 713-14 (1947) (interpreting the meaning of "employee" under the Social Security Act (SSA)).

135331 U.S. 722, 723, 728-31 (1947) (assessing the scope of "employee" under the FLSA).

156332 U.S. 126, 130-32 (1947) (interpreting the meaning of "employee" when applied to social legislation).

157 Silk, 331 U.S. at 712 (footnotes and citations omitted). 
On the same day that Silk was decided, the Rutherford Court held that the existence of an employer-employee relationship does not depend on formalities constructed by the employer; ${ }^{158}$ rather it depends on circumstances of the whole activity. The Court noted that the FLSA provided comprehensive definitions that should be interpreted broadly enough to cover persons and relationships that, before the enactment of the FLSA, did not fall under the employeremployee classification. ${ }^{159}$ The economic reality doctrine was made explicit in Bartels, where the Court established that "employees are those who as a matter of economic reality are dependent upon the business to which they render service." 160

Hence, the economic reality doctrine can be summarized as follows: 'the term 'employee' when used in social and labor legislation should be interpreted in light of the purpose of the legislation." 161 Based on this principle, the economic reality doctrine has evolved into a comprehensive determination of the nature of the work in relation to the regular business of the superior. ${ }^{162}$ This is known as the relative-nature-of-work test. ${ }^{163}$

The relative-nature-of-work test can be viewed as a test of the degree of exclusivity involved in the relationship between the superior and subject. That is, the test can turn on the degree of integration between the responsibilities or actions of superior and subject; and the degree of the subject's dependence on the superior.

Courts that have interpreted the employee-contractor distinction under either of the two tests have appeared to shift the emphasis from the right-to-control-details test to the relative-nature-of-work

158 The Court found that "[w] $w$ here the work done, in its essence, follows the usual path of an employee, putting on an 'independent contractor' label does not take the worker from the protection of the Act." Rutherford, 331 U.S. at 729.

159 See id. at 728-29.

160 Bartels, 332 U.S. at 130 (emphasis added).

161 LARSON, supra note $132, \S 43.41$, at $8-12$. Larson provides the following explanation:

[I]f the need being met by the legislation is regulation of collective bargaining, the term "employee" may well include all workers for whom such bargaining is normal and appropriate; and if the evil aimed at by the legislation is insecurity confronting workers who may undergo temporary unemployment, the term "employee" should include workers who, as a matter of economic reality, are subject to that hazard.

Id.

162 See id. $\$ \S 43.41-.51$, at $8-11$ to -25 .

${ }^{163}$ See infra notes 199-205 and accompanying text (applying test to the structure of the garment industry). 
test. ${ }^{164}$ An analysis of the apparel industry with consideration to both tests will provide the necessary framework for advancing manufacturer liability for garment sweatshop conditions.

\section{MANUfacturer LiabiLITY}

\section{A. Measures Directed Against Manufacturers}

The manufacturer-liability approach has already been the subject of legislative and administrative attempts to enforce fair labor standards. These legislative attempts by and large have been ineffective because they either rely on inadequate enforcement resources or have been rejected before enactment. In principle, however, these attempts demonstrate that judicial imposition of manufacturer liability does not mark a drastic departure from preexisting remedial notions.

\section{Use of "Hot Goods" Sanctions}

Under the so-called "hot goods" provision of the FLSA, ${ }^{165}$ it is unlawful for anyone to transport any goods produced in violation of the provisions of the FLSA. Pursuant to this provision, federal officials have successfully threatened apparel manufacturers with a "hot goods" freeze on the shipment of their products unless they pay back wages owed by the manufacturers' contractors, or barred shipment altogether. ${ }^{166}$ In California, for instance, the U.S. Department of Labor's Wage and Hour Division has used the law to crack down on not only sweatshop owners, but also manufacturers who ship "hot goods" to retailers by barring the shipment of any such goods. ${ }^{167}$

Unfortunately, the "hot goods" provision is severely limited because persons other than "employers" can only be sanctioned

164 See generally LARSON, supra note 132, § 43.54, at 8-32 (citing Haynie v. Tideland Welding Serv., 631 F.2d 1242, 1244 (5th Cir. 1980) and Oilfield Safety \& Mach. Specialties, Inc. v. Harman Unlimited, Inc., 625 F.2d 1248, 1253-54 (5th Cir. 1980)).

165 See 29 U.S.C. $\$ 215(a)(1)$ (1988).

${ }^{166}$ See Sward \& Wallace, supra note 17, at A15 (outlining various attempts at enforcement of federal labor standards by authorities). Until recently, the "hot goods" provision has been used only infrequently in order to force sewing shop owners to pay the minimum wage. Today, officials are testing its effectiveness against wage, overtime, homework, and child labor violations. See Efron, supra note 120 , at A3.

${ }^{167}$ See Efron, supra note 120, at A3; Clean Up the Sweatshops, supra note 101, at B6. 
through injunctions initiated by government enforcement agencies $^{168}$ and criminal penalties. ${ }^{169}$ In fact, the Department of Labor typically brings an injunctive suit against a manufacturer only after sanctions against sweatshop owners have repeatedly led labor officials to the same manufacturer. ${ }^{170}$ Moreover, the FLSA limits civil actions to actions brought against the "employer."171 Thus, without judicial extension of liability under the FLSA to the manufacturer, the garment worker is denied the opportunity to initiate any civil action against the manufacturer.

The "hot goods" approach taken by federal labor officials essentially provides for the enforcement of labor standards through the imposition of liability on the manufacturer. At the very least, therefore, current utilization of the "hot goods" provision signals the recognition that one way of curbing sweatshop labor in the apparel industry is to target the manufacturer. For the "hot goods" approach to work effectively, however, sufficient resources must still be dedicated to enforcement. Similarly, the success of other types of legislation directed at the manufacturer, if enacted, would hinge on the availability of adequate enforcement resources.

\section{Current Legislative Proposals for Manufacturer Liability}

Recently, the California legislature approved a bill targeted at manufacturers. ${ }^{172}$ It explicitly provided for the joint liability of garment manufacturers for labor law violations committed by their subcontractors. ${ }^{173}$ The bill, however, was vetoed by then Gover-

${ }^{168}$ See 29 U.S.C. $\$ 211$ (a) (1988) ("Administrator shall bring all actions under section 217 [(injunction proceedings)] of this title to restrain violations of this chapter."); see also id. $\S 217$ (describing injunction proceedings); GAO, NEw YORR CrTY, supra note 6, at 40-41 (explaining that the Department of Justice is authorized to bring criminal actions, but neither criminal sanctions nor civil injunctions are used extensively).

${ }_{169}$ See 29 U.S.C. $\$ 216($ a) (providing for fines and imprisonment).

170 See Joanna Ramey, Guess-Labor Dept. Contractor Pact Only the First, WOMEN's WEAR DAILY, Aug. 6, 1992, at 15 (statement of Joe Villarreal, Department of Labor regional administrator for Southern California).

171 See 29 U.S.C. \$ 216(b) (outlining actions brought by employees); id. § 216(c) (describing actions brought by the government). Employees are limited to actions to recover unpaid minimum wages or overtime compensation, and liquidated damages. See id. \$ 216(b).

172 The bill was introduced by Assemblyman Tom Hayden (D) of Santa Monica and aimed at cutting off the demand by manufacturers for sweatshop labor. See Frammolino, Legislation, supra note 123, at A29; Ralph Frammolino, Sweatshop Bill Approved, Awaits Governor's Decision, L.A. TIMEs, Aug. 11, 1990, at A34.

173 The proposal targeted manufacturers because sweatshop owners often leave 
nor George Deukmejian. He rejected it on the basis that it would place an "impossible" burden on manufacturers to police the businesses of their subcontractors to ensure compliance with labor standards. ${ }^{174}$ Even more recently, Governor Pete Wilson vetoed another bill ${ }^{175}$ in the California legislature that would hold manufacturers liable for contractor labor law violations.

Holding manufacturers at least partly responsible, however, does not necessarily compel manufacturers to bear the "impossible" burden suggested by opponents of manufacturer liability. One way of relieving that burden would be to hold manufacturers to a general "reasonableness" standard under tort law. In other words, a manufacturer would legally meet its burden by taking "reasonable" actions, such as ensuring that it contracts only with lawfully registered and licensed sewing shops. In addition, the manufacturer could negotiate a fair contract price with the shop owner that would exceed the costs to the shop owner of complying with at least the minimum wage for each employee. Put into context, it is hardly likely that a reasonableness standard would require the manufacturer to oversee every aspect of employment conditions in order to comply with regulations or fulfill its duty. ${ }^{176}$

workers stranded without even the meager earnings they had been promised and "avoid the penalties by simply closing up shop" while "the manufacturer is free to shop around for another contractor." See Frammolino, Legislation, supra note 123, at A29.

174 See Frammolino, Legislation, supra note 123, at A29 (noting that former Governor Deukmejian vetoed the bill because it put too much responsibility on manufacturers).

175 Assembly Bill 1542, Cal. 1991-92 Regular Sess. (amended). The bill, sponsored by Assemblyman Terry Friedman (D) of Los Angeles, provided that anyone engaged in the business of garment manufacturing who contracts operations out to a contractor will be liable to the same extent as the contractor for violations of labor laws relating to wages, hours, industrial homework, minors, and general health and safety. This time around, the rationale for rejecting the bill was that establishing manufacturer liability "would 'only drive the garment industry out of state' to the detriment of the employees and the state's economy." Daniel M. Weincraub, Governor Rejects Bill on Needle Exchange, L.A. TIMES, Oct. 2, 1992, at A3 (quoting Governor Wilson).

${ }_{176}$ The Labor Department recently struck an unprecedented agreement with Guess? Inc. which calls for Guess? to police its contractors to ensure that they do not violate minimum wage, overtime, and child labor laws. See Ramey, supra note 170, at 15; Stuart Silverstein, Guess? Pact to Curb Sweatshop Abuses Praised, L.A. Times, Aug. 6, 1992, at D3; DOL Agrees with Garment Maker's Plan to Police Its Contractors for Violations of Labor Laws, Daily Lab. Rep., Aug. 6, 1992, at A-8. A question remains, however, with respect to the diligence with which a large manufacturer such as Guess? will supervise its contractors. See Silverstein, supra, at D3. 
On the other hand, if the manufacturer knows or has reason to know $^{177}$ that it does business with an unlicensed or unregistered contractor, or if the manufacturer knows or has reason to know that the contract price precludes the contractor from complying with minimum wage standards, then the manufacturer should be held liable for labor law violations resulting from its negligence. The standard of reasonableness, as applied in any other context, would not pose an "impossible" burden on apparel manufacturers. ${ }^{178}$

The California bills discussed above appropriately frame the issue of liability to include possible complicity by manufacturers. Had the bills passed, however, they still would not have eliminated the problem of relying on understaffed government departments for enforcement. ${ }^{179}$ The same can be said for other forms of legislation such as proposed criminal sanctions on manufacturers who contract with shops that have been cited for multiple labor law violations. Thus, without the imposition of liability on manufacturers by judicial interpretation of labor law, manufacturers will not be effectively deterred from contracting with sweatshops and the demand for sweatshop labor will prolong substandard working conditions.

\section{B. Proposals for Judicial Imposition of Manufacturer Liability for FLSA Violations}

From a legislative policy-making standpoint, efforts to regulate labor conditions in the apparel industry face the problems of insufficient deterrence against contractors from operating sweatshops and lack of government resources to enforce existing regulations. For these reasons, the judiciary must take affirmative steps in order to effectuate legislative purposes.

In the absence of effective manufacturer liability legislation, alternative theories can be used to extend adequate protection to garment workers. This Comment proposes a sliding-scale system for

177 Alternatively, if several shops are found to be in violation of labor standards contract with the same manufacturer, it would seem appropriate for some action to be taken against that manufacturer since this would suggest a greater likelihood that the manufacturer frequently imposes unreasonable contract terms or a greater likelihood that the manufacturer knows, or has reason to know of the labor violations. See, e.g., Ramey, supra note 170 and accompanying text (noting that frequency of contracts to sweatshop operators can lead to injunctive action).

${ }^{178}$ Such a standard would in no way impose strict liability-that is, holding the maufacturer accountable without any consideration of fault.

179 See supra notes $103-06$ and accompanying text. 
determining manufacturer liability consisting of three steps: (1) the use of the two determinative tests for employee-contractor status; (2) the application of a tort or "reasonableness" standard to the manufacturer's actions; and (3) an analysis of the public policies and equitable principles involved in the structure of the apparel industry.

\section{Employee Versus Contractor Status}

The initial determination to be made for purposes of the FLSA is whether the sweatshop owner should be deemed an effective employee of, or a truly independent contractor to, the manufacturer. Under either of the two determinative tests (the right-to-controldetails test and the relative-nature-of-work test), ${ }^{180}$ a court may find that the relationship between manufacturer and shop owner is more like one between employer and employee than one between client and contractor.

The finding of an employer-employee relationship would ultimately make the manufacturer vicariously liable for violations of the garment worker's labor rights under respondeat superior. This would be analogous to a situation in which the shop owner acts as an agent for the manufacturer. Another way to view the relationship would be to envision it as a joint employership ${ }^{181}$ between the manufacturer and the shop owner. Under this scheme, the manufacturer and shop owner would be considered simultaneous employers of the garment worker. ${ }^{182}$

${ }^{180}$ See supra notes 140-64 and accompanying text (discussing the judicial development of the tests).

181 See infra notes 206-07 and accompanying text.

182 A district court noted:

A joint employment relationship is generally deemed to exist (1) where one employer is acting directly or indirectly in the other's interest in relation to the employee and (2) where the employers are "not completely disassociated with respect to the employment of a particular employee and may be deemed to share control of the employee, directly or indirectly, by reason of the fact that one employer controls, is controlled by, or is under common control with the other employer."

Maldonado v. Lucca, 629 F. Supp. 483, 487 (D.N.J. 1986) (quoting 29 C.F.R. $\S 791.2(\mathrm{~b})(2),(3)$ (1986)). 


\section{a. Manufacturers' Right to Control Details}

\section{i. Right-to-Control-Details Test}

The basic question under the control-of-details test is whether the degree of control of the details of production exceeds what is necessary to obtain the desired result. ${ }^{183}$ In the apparel industry, examples of "details" would include pricing, volume of production, turnaround time, and quality control.

The decisive factor under the control-of-details test is the "ultimate right of control" and "not the overt exercise of that right." 184 Indeed, the relevant measure of control is not the degree of control actually exercised, but rather the "ultimate right to dictate the method of work ${ }^{185}$ should the occasion to do so arise. ${ }^{186}$

The factors evidencing control include: the method of payment (by time or by job), ${ }^{187}$ the furnishing of equipment, and the right to fire. ${ }^{188}$ These factors, however, do not operate with equal force in both directions-although strong evidence of any one of these factors can by itself prove an employment relationship, contrary evidence can only offer a mildly persuasive showing of independent contractorship, if any. ${ }^{189}$ For example, while the furnishing of equipment by the superior is evidence of the existence of an employer-employee relationship, the furnishing of equipment by the subject (or lack of furnishing of equipment by the superior) is not evidence of equal and opposite weight that the relationship is an independent contractorship. ${ }^{190}$

183 See LARSON, supra note $132, \S 44.21$, at 8-66 to -75 ; see also Davidson, supra note 146, at 207 (" $[\mathrm{T}]$ he basic ingredient . . . is . . . the employer's right to direct the manner of performance of the employee's duties.").

184 LARSON, supra note $132, \S 44.00$, at $8-43$.

${ }^{183} \mathrm{Id}$. § 44.10, at 8-63.

186 See id. at 8-43 to -63. For examples of cases where there is an exercise without a right, or a right without it being exercised, see $i d$. at 8-62 to -67 .

${ }_{187}$ Payment by time would indicate an employment relationship.

188 See LARSON, supra note 132, § 44.31, at 8-89.

189 See id. at 8-90 ("Independent contractorship . . . is established usually only by a convincing accumulation of these and other tests, while employment ... can if necessary often be solidly proved on the strength of one of the ... items . ...").

190 See id. at 8-89, 8-90 (outlining the weight of individual factors). 


\section{ii. Application to Garment Sweatshop Industry}

Typically, the manufacturer pays the shop owner by the job or piece $^{191}$ and the shop owner furnishes the equipment, such as sewing machines and pressers. In the absence of any direct evidence of control, these factors appear to support a finding that the shop owner is an independent contractor instead of an employee relative to the manufacturer. But because the individual factors evidencing control do not work with equal force in both directions, ${ }^{192}$ these two factors alone do not suffice for the determination of whether the shop owner is an employee or an independent contractor. Payment by the job or piece and supply of equipment by the shop owner do not substantiate a contractorship with as much force as payment by time and supply of equipment by the manufacturer substantiate an employment relationship. ${ }^{193}$

Given these circumstances, a case can turn on the extent of the manufacturer's right to terminate the contract or right to fire the shop owner. ${ }^{194}$ A case-by-case determination must be made as to the manufacturer's right to fire, which is often enough to establish control. Control (and therefore employment) need only be established by one principal factor, whereas independence (and therefore contractorship) requires the "convincing accumulation" of factors. ${ }^{195}$

If employment status cannot be determined by the principal factors, other considerations may become relevant. Factors such as the use of unskilled labor, the frequency of contacts between manufacturer and shop owner, and whether the manufacturer provides designs, specifications, fabrics, or on-sight inspections can contribute to a court's determination of whether a shop owner is independent to determine if an employment relationship exists.

191 Shop owners are paid by the contracted job. See supra notes $34-37$ and accompanying text. For a description of the piecework wage system, see supra notes 72-74 and accompanying text.

192 See LARSON, supra note $132, \S 44.31$, at 8-89, 8-90; supra text accompanying notes 189-90 (discussing how employment can be established based on the strength of one factor as opposed to independent contractorship, which requires the "convincing accumulation" of factors).

193 See LARSON, supra note $132, \$ 44.31$, at 8-89, 8-90 (countering, again, the assumption that these tests work with equal force in both directions).

${ }_{194}$ See, e.g., Real v. Driscoll Strawberry Assocs., 603 F.2d 748, 755 (9th Cir. 1979) (using evidence that an employer can fire employees to substantiate a finding of an employment relationship).

195 See LARSON, supra note $132, \S 44.31$, at 8-90. 
Some courts have inferred an employment status by focusing on the employer's control of terms such as pricing, volume, and turnaround time. ${ }^{196}$ In the garment sweatshop industry, the manufacturer can usually dictate these terms of the contract because the manufacturer possesses disproportionately greater bargaining power than the shop owner. ${ }^{197}$ This provides additional support for a finding of an employment relationship.

In sum, the typical relationship between manufacturer and shop owner in the garment industry, when viewed under the right-tocontrol-details test, reflects an employment relationship more closely than an independent contractorship.

\section{b. Relative Nature of Contractors' Work}

\section{i. Relative-Nature-of-Work Test}

The movement towards the relative-nature-of-work test and away from the right-to-control-details test ${ }^{198}$ does not detract from the closeness between the manufacturer-shop owner relationship and an employer-employee relationship. Two questions central to the relative-nature-of-work test are: (1) whether the work constitutes an integral part of the regular business of the employer; and (2) whether the worker (shop owner) maintains an independent business or provides a professional service. ${ }^{199}$ The second question requires not only an examination of the shop owner or the job, but also a determination of independence based on an assessment of how separate and public the business service provided by the shop owner is relative to the employer. ${ }^{200}$

196 See, e.g., Johns v. Jarrard, 927 F.2d 551, 556 (11th Cir.) (noting that, under Georgia law, "a hospital may subject itself to vicarious liability for the malpractice of its . . physicians merely by assuming control over the time of their performance"), reh'g denied, 935 F.2d 1297 (1991); Dole v. Snell, 875 F.2d 802, 806 (10th Cir. 1989) (noting that for cake decorators, "volume of cake orders determined the length of the work day, including long overtime hours whenever necessary"); Usery v. Pilgrim Equip., 527 F.2d 1308, 1312 (5th Cir.), cert. denied, 429 U.S. 826 (1976) (basing a finding of dependence on, among other things, the prices set by the employer).

197 See supra notes $38-46$ and accompanying text; infra notes 214-18 and accompanying text.

198 See supra notes $149-64$ and accompanying text.

199 See LARSON, supra note $132, \S 45.00$, at 8-193.

200 See id. $\$ 45.31$, at 8-234 (exemplifying this "theory of relativity" in the case of a window washer who had one large customer in a clientele of small customers, and thus had an employer-employee relationship with the large client). 


\section{ii. Application to Garment Sweatshop Industry}

Because the work being done by garment workers is an integral part of the regular business of the manufacturer, and because the shop owners do not furnish an independent business or professional service relative to the manufacturer, an employment relationship can be established. ${ }^{201}$ The fact that the shop owners provide all the labor except for design and marketing work underscores the integral nature of the work provided by the sewing shop owners to the manufacturer's business. ${ }^{202}$ No contract, and thus no production, would exist without the shop owners. The integrated nature of garment production in the retail apparel business and the symbiotic relationship between the shop owner and manufacturer support the view that the industry as a whole is a common enterprise. ${ }^{203}$

Whether an individual shop owner furnishes an independent business or professional service depends on the exclusiveness of the contract, that is, whether the manufacturer buys most if not all of the shop owner's production, or the extent to which the shop owner

201 See id. $\$ 45.00$, at 8-193.

202 See Part II, supra, for a detailed description of the garment industry. A district court provided the following description:

The jobber is an independent business enterprise, having its own employees and its own labor-management relations. Similarly, the contractors and subcontractors, as independent business concerns, operate their own shops. Together they form a single integrated process of production; and, although ostensibly separate and unrelated concerns, they are totally dependent upon each other for their economic existence.

Yet, because the jobber initiates the manufacturing process, and because the contractor relies entirely upon the jobber for its work, a hierarchical structure, with the jobber at the pinnacle, evolved which lead to abuses .... The jobber doled out work to the lowest bidder, forcing contractors to compete by reducing costs. The net result of this competition was the development of sweatshops in which employees worked for substandard wages under substandard working conditions.

Botany Indus., Inc. v. New York Joint Bd., Amalgamated Clothing Workers, 375 F. Supp. 485, 494 (S.D.N.Y.) (emphasis added), vacated on other grounds sub nom. Robb v. New York Joint Bd., 506 F.2d 1246 (2d Cir. 1974).

${ }^{203}$ See, e.g., Dole v. Snell, 875 F.2d 802, 811-12 (10th Cir. 1989) (holding that the work of cake decorators is integral to the business of selling cakes); Brock v. Superior Care, Inc., 840 F.2d 1054, 1059 (2nd Cir. 1988) (holding that nursing work is an integral part of defendants's health care service). 
economically depends on the contract. ${ }^{204}$ This factor requires, however, a case-by-case analysis. ${ }^{205}$

\section{c. Joint Employer Doctrine}

If the above determinative tests do not sufficiently demonstrate an employment relationship between manufacturer and shop owner, courts can still impose manufacturer liability under the joint employer doctrine using the standard set forth in Hodgson v. Griffin $\mathcal{E}$ Brand of McAllen, Inc. ${ }^{206}$ In determining that a crew leader and a grower were joint employers of a farm worker, the court in Hodgson held: "[I]ndependent contractor status does not necessarily imply the contractor is solely responsible for his employees under the Fair Labor Standards Act. Another employer may be jointly responsible for the contractor's employees. ${ }^{207}$

An examination of the total "economic reality" offers courts a basis for establishing joint employership between manufacturer and shop owner. This test, which would factor in the relative economic and bargaining power of manufacturer and sweatshop owner into the totality of the circumstances, may indicate that the sweatshop owner is in reality little more than an agent of the manufacturer. By focusing on the real power structure in the garment industry, the manufacturer's immunity from liability for labor violations occurring in garment sweatshops can be penetrated.

204 The terms of the contract are dictated by the manufacturer, who has disproportionately greater bargaining power than the shop owner. See infra notes 214-18 and accompanying text.

205 See, e.g., Fegley v. Higgins, 760 F. Supp. 617, 622 (E.D. Mich. 1991) ("Evaluating a worker's economic reality is a fancy way of asking what the worker's job is like. A court need not rely on rote application of a balancing test in order to answer such a simple question.").

${ }^{206}$ Hodgson v. Griffin \& Brand of McAllen, Inc., 471 F.2d 235 (5th Cir.), cert. denied, 414 U.S. 819 (1973); see also Real v. Driscoll Strawberry Assocs., 603 F.2d 748, 756 (9th Cir. 1979) (" $[$ I] ndependent contractor status . . . does not . . . negate the possibility that the contractee may be a joint employer of those workers under the FLSA."); supro notes 172-75 and accompanying text (proposed legislation intended to make manufacturers jointly liable).

${ }^{207}$ Hodgson, 471 F.2d at 237 (citations omitted). 


\section{Tort Approach to Manufacturers' Actions and Labor Violations}

If a court fails to determine through either the right-to-controldetails or relative-nature-of-work test that the shop owner is closer to an employee or joint employer than an independent contractor relative to the manufacturer, then the court can turn to the reasonableness of the manufacturer's actions. If the court determines the manufacturer acted unreasonably, then the manufacturer will be held liable for the violations of the garment workers' rights in the contractor's sweatshop. ${ }^{208}$

As discussed earlier, the reasonableness of the manufacturer's actions can be determined by the manner in which business is conducted. A heightened industry standard of reasonableness can be applied based on the manufacturer's resources, access to federal or state documentation on garment shops, and ability to draft contract terms that do not force sewing contractors to violate labor standards. ${ }^{209}$

This approach inevitably entails a sliding-scale determination of the manufacturer's good faith dealings and its ability to determine whether the contractor operates a sweatshop. Elements such as those involved in joint tort liability ${ }^{210}$ can facilitate liability assessment. The relative contributions of the manufacturer and the contractor towards the violation of FLSA standards can be used to determine the extent of the manufacturer's liability. Under this joint-tort-feasor approach, ${ }^{211}$ a court can find relative liabilities

${ }^{208}$ See supra notes 176.78 and accompanying and preceeding text (describing a standard of reasonableness that would not pose an "impossible" burden on apparel manufacturers).

${ }^{209}$ Depending on the number of workers at a particular sewing shop and the costs of maintaining that shop, one can assess whether the shop owner will be forced to pay below minimum wage or assign industrial homework when given the required quality, volume, turnaround time, and the desired profit margin of the product. The following is an example based on a simple calculation: If the multiplicative product of minimum wage and (wo)man-hours (based on quality and volume) exceeds the contract price offered by the manufacturer, then chances are likely that the shop owner who agrees to such a contract will violate minimum wage laws. "You must put some of the burden on [those] who know it couldn't be made at legitimate operations because it's just too cheap." Sward \& Wallace, supra note 17, at A15 (statement of Carl Priestland, chief economist for the American Apparel Manufacturers Association).

${ }^{210}$ Joint liability is owed to a third party by two or more parties together where by their common neglect the third party is injured. See W. PAGE KeETON ET AL., PROSSER AND KEETON ON THE LAW OF TORTS \$46, at 322-24 (5th ed. 1984).

21 The manufacturer and the shop owner can be jointly or severally liable for the 
based upon the calculation of pro rata contributions of the parties, or simply transfer the entirety of damages incurred by the garment worker to the more or most culpable party. ${ }^{212}$

\section{Public Policies and Equitable Principles}

As a final test, in the event that the manufacturer is not found liable under any of the above approaches, the court should consider whether public policies or principles of equity may warrant a finding of liability.

Supporters of imposing liability on manufacturers involved with sweatshop contractors rely in part on a deep pocket analysis. The manufacturer, unlike the sweatshop contractor, can pass the costs of compliance with the FLSA on to consumers; therefore the manufacturer is better able to bear the financial burden. Currently, however, the apparel manufacturer merely reaps benefits from the sweatshop system without shouldering any of the responsibilities for the system's exploitation of garment workers. In essence, the current system allows the social costs of sweatshop labor to be borne by the sweatshop owners or operators and garment workers instead of being more efficiently and equitably allocated upwards to the manufacturers, retailers, and ultimately to consumers. ${ }^{213}$

In addition to being the best risk allocator by virtue of having the deepest pocket, the manufacturer, at the top of the apparel industry structure, can also be deemed the party most culpable for the violation of garment workers' labor rights because the manufacturer ultimately dictates the garment shop conditions by exercising its power over the production contract. A primary consideration in assessing the fairness of business contracts in the apparel industry is the relative bargaining power of the parties. As discussed above, the contractor generally has little or no bargaining power relative to the manufacturer. ${ }^{214}$ While contractors fight among themselves in underbidding price wars in order to survive, the manufacturer retains the luxury of conducting business wherever it is least

same injury to the garment worker. See id. $\S 47$, at $326-28$ (concluding that joint liability is found where defendants had a common duty, even though each tortfeasor may be sued severally).

212 See id. $\$ 52$, at $348-52$ (illustrating situations where damages may be capable of apportionment).

213 See supra note 148 and accompanying text (commenting on the efficiency of vicarious liability).

214 See supra notes $38-46$ and accompanying text. 
expensive. ${ }^{215}$ Thus, the usual garment production contract contains terms dictated by the manufacturer, whose oversupply of contractors $^{216}$ grants it considerable leverage. The shop owner complies with these terms because of a desperate fear of losing the contract.

From a moral standpoint, the manufacturer condemns the garment worker to substandard wages and employment conditions when it sets the contract price unreasonably low relative to the amount of labor needed and other costs involved. ${ }^{217}$ Because vicious competition among contractors enables the manufacturer to play them against each other, ${ }^{218}$ contractors are forced to "choose" between going out of business or maintaining substandard shops. On the other hand, manufacturers are quite free to choose among the available contractors with whom they will do business.

\section{NLRA GARMENT INDUSTRY PROVISO}

The proposal to extend liability to the manufacturer under the FLSA essentially crafts an exception to the employee-contractor distinction for the apparel industry. In similar fashion, provisions in the NLRA also make an exception for the apparel industry. ${ }^{219}$ Therefore, apparel manufacturer liability for violations of the FLSA would be consistent with the recognition of the peculiar nature of the industry expressed in the NLRA.

The NLRA, which regulates relations between employers and employees, defines and provides a comprehensive list of what constitutes an "unfair labor practice." 220 The garment industry

${ }^{215}$ See Dygert III \& Shibata, supra note 33, at 64-65 (describing how the apparel industry contracting system favors manufacturers).

${ }^{216}$ A president of a women's wear manufacturer claims that a dozen garment contractors come to his door each day to ask for business. See Efron, supra note 120, at A19.

217 One high-ranking federal labor official noted:

[The manufacturers] know exactly how long it takes because they have (sample makers) in their own shops who run through it to find out how long it takes ... They use that to beat the guys down. ... They can figure out the math, but they beat it down to the lowest price. They say, "If you don't want to do it, fine, we'll go down the street to someone else." Id. at A18-A19.

${ }^{218}$ See Dygert III \&c Shibata, supra note 33, at 64; supra notes $38-46$ and accompanying text.

${ }^{219}$ See 29 U.S.C. $\$ 158(e)$ (1988) (explicitly exempting the apparel industry).

220 See id. § 158(a)-(b). 
exception, ${ }^{221}$ however, exempts labor organizations and employers in the apparel and clothing industry from prohibitions against what would otherwise be unfair labor practices: secondary boycotts $^{222}$ and "hot cargo" agreements. ${ }^{223}$

\section{The garment industry proviso reads as follows:}

[F]or the purposes of this subsection and subsection (b)(4)(B) of this section the terms "any employer", "any person engaged in commerce or an industry affecting commerce", and "any person" when used in relation to the terms "any other producer, processor, or manufacturer", "any other employer", or "any other person" shall not include persons in the relation of a jobber, manufacturer, contractor, or subcontractor working on the goods or premises of the jobber or manufacturer or performing parts of an integrated process of production in the apparel and clothing industry.

Id. $\$ 158$ (e) (second proviso).

${ }^{222} \mathrm{~A}$ secondary boycott is defined as "[a]ny combination if its purpose and effect are to coerce customers or patrons, or suppliers through fear of loss or bodily harm, to withhold or withdraw their business relations from employer who is under attack." BLACK's LAW DICTIONARY 1351 (6th ed. 1990). The NLRA, in detailing the enforceability of contracts or agreements to boycott any other employer, provides that:

It shall be an unfair labor practice for any labor organization and any employer to enter into any contract or agreement, express or implied, whereby such employer ceases or refrains or agrees to cease or refrain from handling, using, selling, transporting or otherwise dealing in any of the products of any other employer, or to cease doing business with any other person, and any contract or agreement entered into heretofore or hereafter containing such an agreement shall be to such extent unenforceable and void ....

29 U.S.C. § 158(e).

${ }^{223} \mathrm{~A}$ hot cargo agreement is defined as a "[v]oluntary agreement between union and neutral employer by which latter agrees to exert pressure on another employer with whom union has a dispute; by, for example, ceasing . . . from . . . dealing in any of the products of any other employer the union has labeled as . . 'hot'." BLACK's LAW DICTIONARY, supra note 222, at 738.

The NLRA, in detailing unfair labor practices by labor organizations, provides that: agents-

It shall be an unfair labor practice for a labor organization or its

(4)(i) to engage in, or to induce or encourage any individual employed by any person engaged in commerce or in an industry affecting commerce to engage in, a strike or a refusal in the course of his employment to use, manufacture, process, transport, or otherwise handle or work on any goods, articles, materials, or commodities or to perform any services; or (ii) to threaten, coerce, or restrain any person engaged in commerce or in an industry affecting commerce, where in either case an object thereof is-

(B) forcing or requiring any person to cease using, selling, handling, transporting, or otherwise dealing in the products of any other producer, processor, or manufacturer, or to cease doing business with any other 
Courts have adhered to the protective language of the NLRA in their analyses of the garment industry proviso. In Danielson $v$. Joint Board of Coat, Suit and Allied Garment Workers' Union, ${ }^{224}$ the Second Circuit reversed an injunction restraining a garment workers' union from picketing a jobber for its refusal to agree to limit itself to union contractors. ${ }^{225}$ The court emphasized the garment workers' need for hot cargo agreements because of the uniquely oppressive nature of the industry. ${ }^{226}$ The court also turned to the legislative history of the NLRA, deferring to the argument that " $[t]$ he ban on secondary boycotts . . . 'is merely intended to prevent ... injuring a third person who is [not] involved in any way in the dispute" and "is not intended to apply to a case where the third party is, in effect, in cahoots with or acting as a part of the primary employer." 227 The court concluded that secondary picketing is "clearly permissible" in the garment industry. ${ }^{228}$

The Danielson holding is consistent with the Ninth Circuit's earlier holding in Construction Laborers Union v. $N L R B^{229}$ that the NLRA permits, in the garment industry, picketing "not only to

person, or forcing or requiring any other employer to recognize or bargain with a labor organization as the representative of his employees ....

29 U.S.C. § 158(b).

${ }^{224}$ Danielson v. Joint Bd. of Coat, Suit \& Allied Garment Workers' Union, 494 F.2d 1290 (2d Cir. 1974).

225 See id. at 1230-31.

${ }^{226}$ Judge Friendly wrote for the majority:

Garment manufacturers, in an effort to avoid unionization, largely abandoned their "inside shops," transformed themselves into jobbers, and then engaged contractors to do the actual manufacturing. "The jobber had no direct dealing with employees, was not responsible to them for wages, and was unconcerned with hours and adequate standards .... The contractors were in fierce competition with one another for the patronage of jobbers and inside manufacturers. The essential basis of this intense competition was reduced labor costs. The brunt of this economic rivalry was borne by the workers and reflected itself in depressed wages and substandard labor conditions." Since unionization of one contractor would be ineffective if the jobber could turn to a non-union competitor, the weapon developed by the union to meet this was to require the jobber to agree to deal only with unionized contractors.

Id. at 1234 (quoting Greenstein v. National Skirt \& Sportswear Ass'n, 178 F. Supp. 681, 687 (S.D.N.Y. 1959), appeal dismissed, 274 F.2d 430 (2d Cir. 1960)).

${ }^{227}$ Id. at 1235 (quoting 95 CoNG. REC. 8709 (1949) (statement of Senator Taft on proposed amendments to the newly enacted Taft-Hartley Act)).

228 Id. at 1235.

229323 F.2d 422 (9th Cir. 1963). 
secure an agreement but also to enforce it." ${ }^{230}$ On the other hand, in all other industries except construction, picketing either to secure or enforce an agreement is prohibited. ${ }^{231}$

The garment industry proviso in the NLRA and its judicial interpretation ${ }^{232}$ exemplify the need to provide special consideration for the protection of the garment sweatshop worker because of the nature of the apparel industry. Without similar exceptional treatment under the FLSA or some other form of meaningful and effective legislation, the garment worker's labor rights will remain unprotected.

\section{CONCLUSION}

The persistence and prevalence of sweatshop conditions in the domestic apparel industry compels a more rigorous search for remedies for the injuries suffered by the garment sweatshop worker, the supplier of sweatshop labor. While the garment worker continues to tolerate substandard working conditions, the approach to solving the sweatshop problem must be taken from the demand side in addition to the supply side. Limiting the enforcement of labor laws to putting the responsibility solely on the sweatshop owner or operator is inadequate because of the unique nature of the industry. In order to effectively control the demand for sweatshop labor, the apparel manufacturer-the true beneficiary of the garment sweatshop system-must be held accountable for the detriment to the worker that corresponds to its own benefit.

230 Id. at 424.

231 See id. at 425.

232 See Botany Indus. v. New York Joint Bd., 375 F. Supp. 485, 494-95 (S.D.N.Y.) (commenting on how "hot cargo" contracts, in the apparel industry developed in order to force employers to operate under union contracts), vacated on other grounds sub. nom. Robb v. New York Joint Bd., 506 F.2d 1246 (2d Cir. 1974); Employing Lithographers v. NLRB, 301 F.2d 20, 26 (5th Cir. 1962) (describing how the apparel industry's oversupply of contractors led to substandard working conditions which could only be improved by "hot cargo" contracts requiring them to unionize). 
